\title{
Facile Synthesis of Highly Congested 1,2-Diphosphinobenzenes from Bis(phosphine)boronium Salts
}

\author{
Supporting Information
}

\author{
Yoshikazu Yamamoto, ${ }^{\dagger}$ Toru Koizumi, ${ }^{\dagger, \dagger}$ Kosuke Katagiri, ${ }^{\dagger, \hbar}$ Yui Furuya, ${ }^{\dagger}$ Hiroshi Danjo, ${ }^{* \dagger}$ \\ Tsuneo Imamoto, ${ }^{\ddagger}$ and Kentaro Yamaguchi ${ }^{*} \dagger$ \\ Department of Pharmaceutical Technology, Faculty of Pharmaceutical Sciences at Kagawa Campus, \\ Tokushima Bunri University, and CREST, Japan Science and Technology Agency (JST), Shido, \\ Sanuki, Kagawa 769-2193, Japan \\ Department of Chemistry, Faculty of Science, Chiba University, Yayoi-cho, Inage-ku, Chiba 263-8522, Japan
}

General. All manipulations were carried out under nitrogen atmosphere. NMR spectra were recorded on a JEOL JNM-ECX (400 MHz for ${ }^{1} \mathrm{H}, 162 \mathrm{MHz}$ for ${ }^{31} \mathrm{P}$, and $100 \mathrm{MHz}$ for ${ }^{13} \mathrm{C}$ ). Chemical shifts were reported in $\delta \mathrm{ppm}$ referenced to an internal tetramethylsilane standard for ${ }^{1} \mathrm{H}$ NMR, and to an external $85 \%$ $\mathrm{H}_{3} \mathrm{PO}_{4}$ standard for ${ }^{31} \mathrm{P}$ NMR. Residual chloroform $\left(\delta 77.0\right.$ for $\left.{ }^{13} \mathrm{C}\right)$ was used as internal reference for ${ }^{13} \mathrm{C}$ NMR. ${ }^{1} \mathrm{H},{ }^{13} \mathrm{C}$, and ${ }^{31} \mathrm{P}$ NMR spectra were recorded in $\mathrm{CDCl}_{3}$ at $25{ }^{\circ} \mathrm{C}$ unless otherwise noted. IR spectra were recorded on a JASCO FT/IR-6300. Optical rotations were recorded on a JASCO P-1030 polarimeter with a sodium lamp. MS (ESI) spectra were recorded on JEOL JMS-T100LC spectrometers. HPLC analyses were performed on a Hitachi L-2130 pump, and L-2450 Diode Array detector with a chiral column. X-ray crystal structure data were collected using a Bruker SMART APEX II diffractmeter with Mo-K $\alpha$ radiation.

Materials. All reagents were obtained from commercial sources and used without further purification. All solvents were freshly distilled. Compound 2 and $(R)-5$ were prepared according to the literature procedure. ${ }^{1}$

\section{Bis(di-tert-butylphosphine)boronium bromide (3a-Br)}

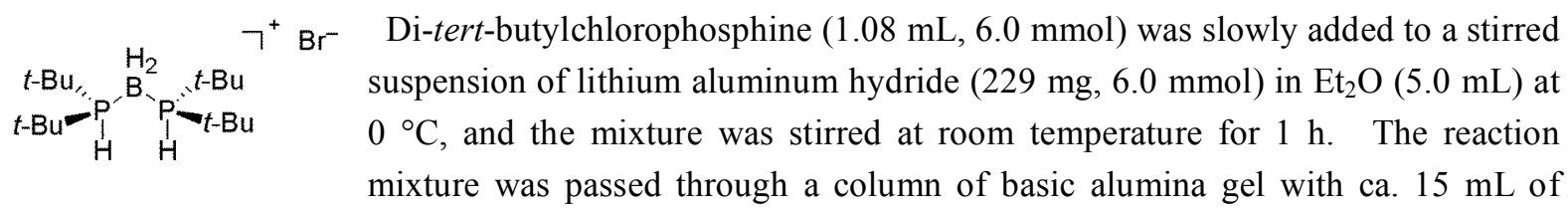

$\mathrm{Et}_{2} \mathrm{O}$ elution. The volatiles were removed in vacuo, and the residue was dissolved in $\mathrm{CH}_{2} \mathrm{Cl}_{2}(10 \mathrm{~mL})$. To the solution was added monobromoborane-methylsulfide complex ( $2.7 \mathrm{~mL}$ of $1.0 \mathrm{M} \mathrm{CH}_{2} \mathrm{Cl}_{2}$ solution, 2.7 mmol) at room temperature, and the mixture was stirred at intact temperature. After $40 \mathrm{~h}$, the volatiles were removed in vacuo, and the residue was purified by column chromatography on silica gel with $\mathrm{CHCl}_{3} / \mathrm{MeOH}(20 / 1$ to $10 / 1)$ to give $\mathbf{3 a} \cdot \mathrm{Br}$ as a white solid (743 mg, 72\%). ${ }^{1} \mathrm{H} \mathrm{NMR}\left(400 \mathrm{MHz}, \mathrm{CDCl}_{3}\right) \delta$ $5.99(\mathrm{~d}, J=410 \mathrm{~Hz}, 2 \mathrm{H}), 1.7-0.6(\mathrm{~m}, 2 \mathrm{H}), 1.49(\mathrm{~d}, J=15 \mathrm{~Hz}, 36 \mathrm{H}) ;{ }^{13} \mathrm{C} \mathrm{NMR}\left(100 \mathrm{MHz}, \mathrm{CDCl}_{3}\right) \delta 32.9$ (m), 28.8; ${ }^{31} \mathrm{P}$ NMR $\left(162 \mathrm{MHz}, \mathrm{CDCl}_{3}\right) \delta 55.8$ (d, $J=95 \mathrm{~Hz}$ ); IR (KBr) 2990, 2966, 2433, 2404, 2302, 1474, $820 \mathrm{~cm}^{-1}$; MS (ESI) $\mathrm{m} / \mathrm{z} 305$ (M-Br); Anal. Calcd. for: C, 49.89; H, 10.47. Found: C, 49.97; H, 10.51 .

${ }^{1}$ Katagiri, K.; Danjo, H.; Yamaguchi, K.; Imamoto, T. Tetrahedron 2005, 61, 4701-4707 


\section{$(S, S)$-Bis(tert-butyl(methyl)phosphine)boronium Iodide $(3 \mathrm{~b} \cdot I)$ and Its meso-Isomer}

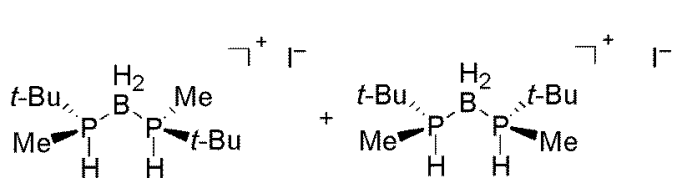

The mixture of $\mathrm{K}_{2} \mathrm{CO}_{3}(25.4 \mathrm{~g}, 183 \mathrm{mmol})$ and tert-butylmethylphosphonium iodide $(8.5 \mathrm{~g}, 36.6 \mathrm{mmol})$ was stirred in $\mathrm{CH}_{2} \mathrm{Cl}_{2}(50 \mathrm{~mL})$ at room temperature. After $1 \mathrm{~h}$, the solution was passed through a column of basic alumina gel with $\mathrm{CH}_{2} \mathrm{Cl}_{2}$ elution to give $\mathrm{CH}_{2} \mathrm{Cl}_{2}$ solution of rac-tert-butyl(methyl)lphosphine. To the solution was added dropwise the mixture of iodine $(2.32 \mathrm{~g}, 9.16 \mathrm{mmol})$ and (S)-tert-butyl(methyl)phosphine-borane $(2.16 \mathrm{~g}, 18.3 \mathrm{mmol})$ in $\mathrm{CH}_{2} \mathrm{Cl}_{2}$, which was previously stirred at room temperature for $7 \mathrm{~h}$. After $24 \mathrm{~h}$, borane-THF complex ( $27.5 \mathrm{~mL}$ of $1.0 \mathrm{M}$ THF solution, $27.5 \mathrm{mmol}$ ) was added at $0{ }^{\circ} \mathrm{C}$, and the mixture was stirred at room temperature for $30 \mathrm{~min}$ (to trap the remaining free phosphine). The reaction mixture was diluted with water and extracted with $\mathrm{CH}_{2} \mathrm{Cl}_{2}$. The combined extract was dried over $\mathrm{Na}_{2} \mathrm{SO}_{4}$. After filtration, the filtrate was concentrated under reduced pressure, and the residue was subjected to column chromatography on silica gel (chloroform/methanol $=20 / 1$ to $10 / 1$ ) to give a diastereomeric mixture of $\mathbf{3 b} \cdot \mathrm{I}$ as a white solid $(4.44 \mathrm{~g}, 70 \%)$. Diastereomerically enriched $(S, S)$ 3b I could be obtained by recrystallization from THF ( $96 \%$ de).

meso-3b·I: ${ }^{1} \mathrm{H}$ NMR $\left(400 \mathrm{MHz}, \mathrm{CDCl}_{3}\right) \delta 6.30(\mathrm{dm}, J=416 \mathrm{~Hz}, 2 \mathrm{H}), 2.2-0.7(\mathrm{~m}, 2 \mathrm{H}), 1.71(\mathrm{dd}, J=6 \mathrm{~Hz}, J$ $=6 \mathrm{~Hz} 6 \mathrm{H}), 1.30(\mathrm{~d}, J=16 \mathrm{~Hz}, 18 \mathrm{H}) ;{ }^{31} \mathrm{P}$ NMR $\left(162 \mathrm{MHz}, \mathrm{CDCl}_{3}\right) \delta-3.7(\mathrm{~m})$.

(S,S)- 3b·I: ${ }^{1} \mathrm{H}$ NMR (400 MHz, $\left.\mathrm{CDCl}_{3}\right) \delta 6.09(\mathrm{dm}, J=416 \mathrm{~Hz}, 2 \mathrm{H}), 2.2-0.7(\mathrm{~m}, 2 \mathrm{H}), 1.74(\mathrm{dd}, J=6 \mathrm{~Hz}$, $J=6 \mathrm{~Hz}, 6 \mathrm{H}), 1.29(\mathrm{~d}, J=16 \mathrm{~Hz}, 18 \mathrm{H}) ;{ }^{13} \mathrm{C} \mathrm{NMR}\left(100 \mathrm{MHz}, \mathrm{CDCl}_{3}\right) \delta 2.8(\mathrm{~d}, J=43 \mathrm{~Hz}), 26.1,27.1(\mathrm{~d}, J$ $=47 \mathrm{~Hz}), 28.4,28.2,27.6(\mathrm{dd}, J=7 \mathrm{~Hz}, J=40 \mathrm{~Hz}), 26.1,2.7(\mathrm{~d}, J=41 \mathrm{~Hz}) ;{ }^{31} \mathrm{P}$ NMR $\left(162 \mathrm{MHz}, \mathrm{CDCl}_{3}\right)$ $\delta-3.7(\mathrm{~m})$. IR (KBr) 2959, 2903, 2865, 2431, 2337, 1465, 893, 868, $808 \mathrm{~cm}^{-1} ;[\alpha]_{\mathrm{D}}^{25}=23.1\left(c 1.0, \mathrm{CHCl}_{3}\right)$; HRMS (ESI): $m / z$ Calcd. for $\mathrm{C}_{20} \mathrm{H}_{56} \mathrm{~B}_{2} \mathrm{IP}_{4}(2 \mathrm{M}-\mathrm{I}): 569.2563$. Found 569.25684.

\section{(S)-(tert-Butyl(methyl)phosphine)(di-tert-butylphosphine)boronium Iodide ((S)-3c-I)}

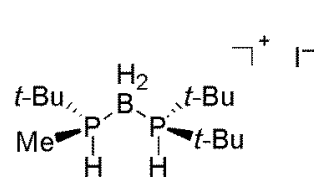

Chloro-di-tert-butylphosphine $(627 \mu \mathrm{L}, 3.30 \mathrm{mmol})$ was slowly added to a stirred suspension of lithium aluminum hydride $(133 \mathrm{mg}, 3.48 \mathrm{mmol})$ in $\mathrm{Et}_{2} \mathrm{O}(4.0$ $\mathrm{mL}$ ) at $0{ }^{\circ} \mathrm{C}$, and the mixture was stirred at room temperature. After $1 \mathrm{~h}$, the solution was passed through a column of basic alumina gel with ca. $10 \mathrm{~mL}$ of $\mathrm{Et}_{2} \mathrm{O}$ elution. The volatiles were removed in vacuo, and the residue was dissolved in $\mathrm{CH}_{2} \mathrm{Cl}_{2}(5 \mathrm{~mL})$. To the solution was added dropwise the mixture of iodine $(323 \mathrm{mg}, 1.27 \mathrm{mmol})$ and (S)-tert-butyl(methyl)phosphine-borane (300 $\mathrm{mg}, 2.54 \mathrm{mmol}$ ) in $\mathrm{CH}_{2} \mathrm{Cl}_{2}$, which was previously stirred at room temperature for $7 \mathrm{~h}$. After stirring at room temperature for $24 \mathrm{~h}$, borane-THF complex $(1.0 \mathrm{~mL}$ of 1.2 M THF solution, $1.3 \mathrm{mmol}$ ) was added at $0{ }^{\circ} \mathrm{C}$, and the mixture was stirred at room temperature for 30 min (to trap the remaining free phosphine). The reaction mixture was diluted with water and extracted with $\mathrm{CH}_{2} \mathrm{Cl}_{2}$, and the combined extract was dried over $\mathrm{Na}_{2} \mathrm{SO}_{4}$. After filtration, the filtrate was concentrated under reduced pressure, and the residue was subjected to column chromatography on silica gel (chloroform/methanol $=20 / 1$ to $10 / 1)$ to give $3 \mathrm{c} \cdot \mathrm{I}$ as a white solid $(793 \mathrm{mg}, 76 \%) .{ }^{1} \mathrm{H}$ NMR $(400 \mathrm{MHz}$, $\left.\mathrm{CDCl}_{3}\right) \delta ; 6.77(\mathrm{dm}, J=403 \mathrm{~Hz}, 1 \mathrm{H}), 5.84(\mathrm{dm}, J=402 \mathrm{~Hz}, 1 \mathrm{H}), 2.2-0.7(\mathrm{~m}, 2 \mathrm{H}), 1.77(\mathrm{dd}, J=6 \mathrm{~Hz}, J=$ $6 \mathrm{~Hz} 3 \mathrm{H}), 1.48(\mathrm{~d}, J=16 \mathrm{~Hz}, 9 \mathrm{H}), 1.41(\mathrm{~d}, J=16 \mathrm{~Hz}, 9 \mathrm{H}), 1.30(\mathrm{~d}, J=16 \mathrm{~Hz}, 9 \mathrm{H}) ;{ }^{13} \mathrm{C}$ NMR $(100 \mathrm{MHz}$, $\left.\mathrm{CDCl}_{3}\right) \delta 32.6(\mathrm{~d}, J=31 \mathrm{~Hz}), 31.9(\mathrm{dd}, J=6 \mathrm{~Hz}, J=31 \mathrm{~Hz}), 28.4,28.2,27.6(\mathrm{dd}, J=7 \mathrm{~Hz}, J=40 \mathrm{~Hz})$, 26.1, $2.7(\mathrm{~d}, J=41 \mathrm{~Hz}) ;{ }^{31} \mathrm{P}$ NMR $\left(162 \mathrm{MHz}, \mathrm{CDCl}_{3}\right) \delta 17.5(\mathrm{~d}, J=91 \mathrm{~Hz}),-0.1(\mathrm{~d}, J=100 \mathrm{~Hz}) ; \mathrm{IR}(\mathrm{KBr})$ $2990,2963,2943,2891,2866,2454,2416,2296,1470,1372,1192,847 \mathrm{~cm}^{-1} ;[\alpha]_{\mathrm{D}}^{23}=13.5\left(c 1.0, \mathrm{CHCl}_{3}\right)$; 
MS (ESI) m/z 263 (M-I); Anal. Calcd. for: C, 40.03; H, 8.79. Found: C, 39.88; H, 8.63.

Typical Procedure for the Preparation of [1,2-Bis(dialkylphosphino)benzene- $\left.\boldsymbol{\kappa}^{\mathbf{2}} \mathbf{P}, \mathbf{P}^{\prime}\right]$ boronium Salts

To a suspension of bis(dialkylphosphine)boronium salt $\quad\left(\begin{array}{lllll}0.74 & \mathrm{mmol}) & \text { and }\end{array}\right.$
$N, N, N^{\prime}, N$ '-tetramethylethylenediamine $(225 \mu \mathrm{L}, 0.74 \mathrm{mmol})$ in THF $(2 \mathrm{~mL})$ was added $n$-BuLi $(930 \mu \mathrm{L}$ of 1.6 $\mathrm{M} n$-hexane solution, $1.48 \mathrm{mmol}$ ) at $-78^{\circ} \mathrm{C}$, and the mixture was warmed to room temperature. After $30 \mathrm{~min}$, a solution of 1,2-difluorobenzenetricarbonylchromium (2) $(0.74 \mathrm{mmol})$ in THF (2 mL) was added to the reaction mixture at $-78^{\circ} \mathrm{C}$. After stirring for an additional $24 \mathrm{~h}$ at $-40{ }^{\circ} \mathrm{C}$, the reaction mixture was diluted with water and extracted with $\mathrm{CHCl}_{3}$. The combined extract was dried over $\mathrm{Na}_{2} \mathrm{SO}_{4}$. After filtration, the filtrate was concentrated under reduced pressure, and the residue was subjected to column chromatography on silica gel (chloroform/methanol $=20 / 1$ to $10 / 1$ ) to give a yellow solid. The solution of a yellow solid in chloroform was exposed to UV under air at room temperature for $1 \mathrm{~h}$. The mixture was passed through a celite pad to give [1,2-bis(dialkylphosphino)benzene- $\kappa^{2} \mathrm{P}, \mathrm{P}$ '] boronium salt.

\section{$(\boldsymbol{R}, \boldsymbol{R})$-[1,2-Bis(tert-butyl(methyl)phosphino)benzene- $\left.\boldsymbol{\kappa}^{2} \mathbf{P}, \mathbf{P}^{\prime}\right]$ boronium Iodide $((\boldsymbol{R}, \boldsymbol{R})-\mathbf{4 b} \cdot \mathbf{I})$}

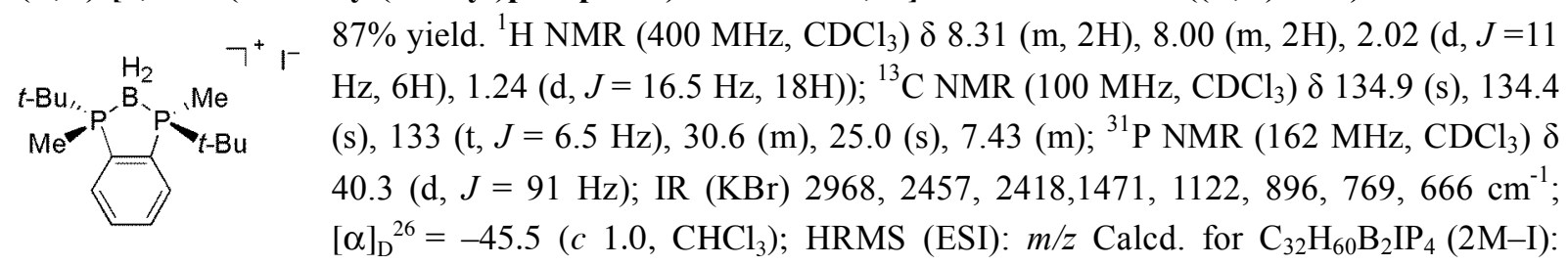

717.2876. Found 717.29327. The ee of the compound was determined to be $>99 \%$ using HPLC analysis on a SUMICHIRAL OA-7000 column. $\mathrm{pH} 3.0$ phosphate buffer/acetonitrile $=70: 30$, flow rate: $1 \mathrm{~mL} / \mathrm{min}$ (retention times: $12.3 \mathrm{~min}($ meso), $15.8 \mathrm{~min}(R, R), 29.2 \mathrm{~min}(S, S)$ ).

(R)-[(1-tert-Butyl(methyl)phosphino-2-di-tert-butylphosphino)benzene- $\kappa^{2} \mathbf{P}, \mathbf{P}$ ']boronium

Iodide $((R)-4 c \cdot I)$

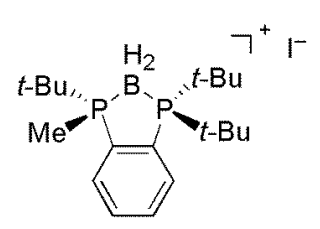

$83 \%$ yield. ${ }^{1} \mathrm{H}$ NMR $\left(400 \mathrm{MHz}, \mathrm{CDCl}_{3}\right) \delta 8.30-8.33(\mathrm{~m}, 1 \mathrm{H}), 8.05-8.09(\mathrm{~m}, 1 \mathrm{H})$, 7.95-8.02 (m, 2H), 2.3-0.8 (m, 2H), 1.89 (d, $J=11 \mathrm{~Hz}, 3 \mathrm{H}), 1.47$ (d, $J=15 \mathrm{~Hz}, 9 \mathrm{H})$, $1.33(\mathrm{~d}, J=15 \mathrm{~Hz}, 9 \mathrm{H}) 1.29(\mathrm{~d}, J=15 \mathrm{~Hz}, 9 \mathrm{H}) ;{ }^{13} \mathrm{C} \mathrm{NMR}\left(100 \mathrm{MHz}, \mathrm{CDCl}_{3}\right) \delta 136.2$ $(\mathrm{d}, J=20 \mathrm{~Hz}), 135.7(\mathrm{~d}, J=20 \mathrm{~Hz}), 134.7-134.6(\mathrm{~m}), 134.3-134.2(\mathrm{~m}), 133.9-133.7$ (m), 133.6-133.4 (m), 121.0 (d, $J=319 \mathrm{~Hz}), 35.5$ (dd, $J=4 \mathrm{~Hz}, J=28 \mathrm{~Hz}), 34.6$ (d, $J$ $=28 \mathrm{~Hz}), 31.9(\mathrm{dd}, J=4 \mathrm{~Hz}, J=36 \mathrm{~Hz}), 28.8,27.7,25.4,6.8(\mathrm{dd}, J=4 \mathrm{~Hz}, J=38 \mathrm{~Hz}) ;{ }^{31} \mathrm{P}$ NMR $(162$ $\left.\mathrm{MHz} \mathrm{CDCl}_{3}\right) \delta 59.5(\mathrm{~d}, J=95 \mathrm{~Hz}), 37.0(\mathrm{~d}, J=91 \mathrm{~Hz})$; IR (KBr) 3086, 2980, 2875, 2474, 2434, 1473, 1262, 1223, 1144, 1030, 896, 760, $637 \mathrm{~cm}^{-1} ;[\alpha]_{\mathrm{D}}{ }^{23}=-12.9$ (c 1.0, $\left.\mathrm{CHCl}_{3}\right)$; Anal. Calcd. for: $\mathrm{C}, 49.39 ; \mathrm{H}$, 7.46. Found: C, 49.45; H, 7.20.

\section{[1,2-Bis(di-tert-butylphosphino)benzene- $\left.\kappa^{2} \mathbf{P}, \mathbf{P}^{\prime}\right]$ boronium Bromide $\left.(4 \mathrm{a} \cdot \mathrm{Br})\right)$}

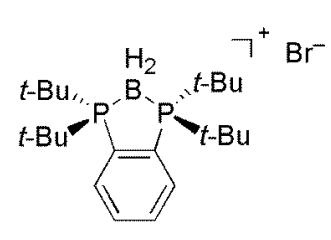

To a suspension of $\mathbf{3 a}(154 \mathrm{mg}, 0.4 \mathrm{mmol})$ and hexamethylphosphoramide (330 $\mu \mathrm{L}, 2.0 \mathrm{mmol})$ in THF $(1 \mathrm{~mL})$ was added $n$-BuLi $(930 \mu \mathrm{L}$ of $1.6 \mathrm{M}$ hexane solution, $1.48 \mathrm{mmol}$ ) at $-78^{\circ} \mathrm{C}$ and the mixture was warmed to room temperature. After $1 \mathrm{~h}$, to this mixture was added chromium complex $2(50 \mathrm{mg}, 0.2 \mathrm{mmol})$ in THF $(2 \mathrm{~mL})$ at $-78{ }^{\circ} \mathrm{C}$ and the mixture was warmed to $70{ }^{\circ} \mathrm{C}$. After $24 \mathrm{~h}, \mathrm{H}_{2} \mathrm{O}(5$ $\mathrm{mL})$ and $\mathrm{CHCl}_{3}(7 \mathrm{~mL})$ were added, and the layers were allowed to separate. After the organic layer was collected, the aqueous layer was extracted with $\mathrm{CHCl}_{3}(7 \mathrm{~mL})$ twice, and the combined organic extract was dried over $\mathrm{Na}_{2} \mathrm{SO}_{4}$. After the solution was filtered, the volatiles were removed in vacuo, and the residue 
was purified by column chromatography on silica gel eluting with $\mathrm{CHCl}_{3} / \mathrm{MeOH}(20 / 1$ to $10 / 1$ to $3 / 1)$ to give $\mathbf{4 a} \cdot \mathrm{Br}$ as a white solid (57.4 mg, 62\%). ${ }^{1} \mathrm{H}$ NMR (400 $\left.\mathrm{MHz}, \mathrm{CDCl}_{3}\right) \delta 8.26-8.21(\mathrm{~m}, 2 \mathrm{H}), 8.18-8.15$ $(\mathrm{m}, 2 \mathrm{H}), 2.3-0.8(\mathrm{~m}, 2 \mathrm{H}), 1.46(\mathrm{~d}, J=15 \mathrm{~Hz}, 36 \mathrm{H}) ;{ }^{13} \mathrm{C} \mathrm{NMR}\left(100 \mathrm{MHz}, \mathrm{CDCl}_{3}\right) \delta 135.4-134.7(\mathrm{~m})$, 135.1-135.0 (m), 134.5, 36.8 (t, $J=30 \mathrm{~Hz}), 29.8 ;{ }^{31} \mathrm{P}$ NMR $\left(162 \mathrm{MHz}, \mathrm{CDCl}_{3}\right) \delta 55.8$ (d, $\left.J=95 \mathrm{~Hz}\right) ; \mathrm{IR}$ (KBr) 2989, 2968, 2872, 2483, 2445, 1371, 1181, 1108, 789, 674; HRMS (ESI): $m / z$ Calcd. for $\mathrm{C}_{22} \mathrm{H}_{42} \mathrm{BP}_{2}$ (M-Br): 379.2855. Found 379.2891; Anal. Calcd. for: C, 57.54; H, 9.22. Found: C, 57.18; H, 9.09.

\section{Typical Procedure for the Preparation of 1,2-Diphosphines}

A mixture of boronium salt $(0.1 \mathrm{mmol})$ and tetrabutylammonium fluoride trihydrate $(63.1 \mathrm{mg}, 0.2 \mathrm{mmol})$ in chrolobenzene $(3 \mathrm{~mL})$ was stirred at $70{ }^{\circ} \mathrm{C}$. After $48 \mathrm{~h}$, the reaction mixture was cooled to room temperature, and the volatiles were removed in vacuo. $\mathrm{Et}_{2} \mathrm{O}$ was added to the residue and the mixture was passed through a column of basic alumina gel with ca. $10 \mathrm{~mL}$ of $\mathrm{Et}_{2} \mathrm{O}$ elution. The volatiles were removed in vacuo to give a 1,2-diphosphines.

\section{$(R, R)-1,2-B i s(t e r t-b u t y l(m e t h y l) p h o s p h i n o) b e n z e n e ~((R, R)-1 b)$}

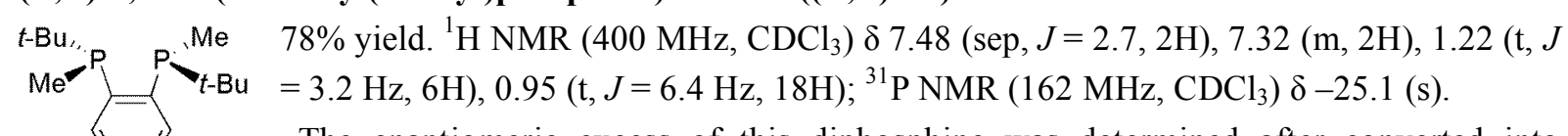

The enantiomeric excess of this diphosphine was determined after converted into diphosphine disulfide derivative by treatment with excess sulfur in refluxing hexane for Mer $20 \mathrm{~h}$. The product was isolated by preparative TLC (hexane/AcOEt $=5 / 1$ ) and the ee of the compound was determined to be $>99 \%$ using HPLC analysis on a Daicel CHIRALPAK AS-H column. EtOH/hexane $=1: 99$, flow rate: $1 \mathrm{~mL} / \mathrm{min}$ (retention times: $20.5 \min$ (meso), $23.3 \min (R, R), 35.9 \min (S, S))$.

\section{(R)-(1-tert-Butyl(methyl)phosphino-2-di-tert-butylphosphino)benzene ((R)-1c)}

$$
\begin{aligned}
& t \text {-Bu, }{ }^{t} t \text {-Bu } \quad 69 \% \text { yield. }{ }^{1} \mathrm{H} \text { NMR }\left(400 \mathrm{MHz}, \mathrm{CDCl}_{3}\right) \delta 7.81-7.78(\mathrm{~m}, 1 \mathrm{H}), 7.58-7.55(\mathrm{~m}, 1 \mathrm{H}), 7.29 \\
& \mathrm{Me}_{t-\mathrm{Bu}}^{t-\mathrm{Bu}}
\end{aligned}
$$

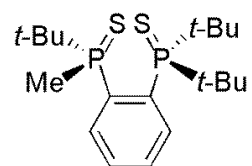

The enantiomeric excess of this diphosphine was determined after converted into diphosphine disulfide derivative by treatment with excess sulfur in refluxing hexane for $20 \mathrm{~h}$. The product was isolated by preparative TLC (hexane/AcOEt $=5 / 1$ ) and the ee of the compound was determined to be $>99 \%$ using HPLC analysis on a Daicel CHIRALPAK AD-H column. $\mathrm{iPrOH} /$ hexane $=1: 99$, flow rate: $0.5 \mathrm{~mL} / \mathrm{min}$ (retention times: $27.2 \mathrm{~min}(R), 30.4 \mathrm{~min}(S)$ ).

\section{1,2-Bis(di-tert-butylphosphino)benzene (1a)}

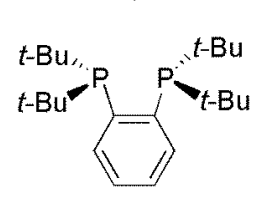

A mixture of boronium salt $(45.9 \mathrm{mg}, 0.1 \mathrm{mmol})$ and tetrabutylammonium fluoride trihydrate $(94.7 \mathrm{mg}, 0.3 \mathrm{mmol})$ in chrolobenzene $(3 \mathrm{~mL})$ was stirred at $70{ }^{\circ} \mathrm{C}$. After 48 $\mathrm{h}$, the reaction mixture was cooled to room temperature, and the volatiles were removed in vacuo. $\mathrm{Et}_{2} \mathrm{O}$ was added to the residue and the mixture was passed through a column of basic alumina gel with ca. $10 \mathrm{~mL}$ of $\mathrm{Et}_{2} \mathrm{O}$ elution. The volatiles were removed in vacuo to give a 1a (57.4 $\mathrm{mg}, 89 \%) .{ }^{1} \mathrm{H}$ NMR $\left(400 \mathrm{MHz}, \mathrm{CDCl}_{3}\right) \delta$ 7.84-7.82 (m, 2H), $7.29(\mathrm{~m}, 2 \mathrm{H}), 1.21(\mathrm{t}, J=5.96,36 \mathrm{H}) ;{ }^{31} \mathrm{P}$ NMR (162 MHz, $\left.\mathrm{CDCl}_{3}\right) \delta 21$ (s). 


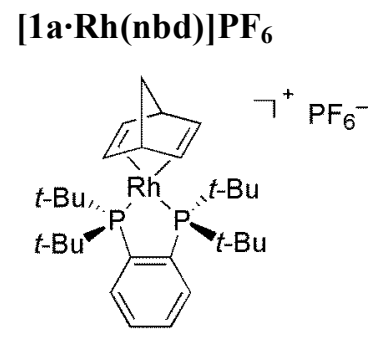

A solution of $\left[\mathrm{RhCl}(\mathrm{nbd})_{2}\right] \mathrm{PF}_{6} \quad\left(\begin{array}{lllll}56.2 & \mathrm{mg}, & 0.13 & \mathrm{mmol})\end{array}\right.$ and 1,2-bis(di-tert-butylphosphino)benzene (1a) $(51.2 \mathrm{mg}, 0.14 \mathrm{mmol})$ in THF (5 $\mathrm{mL}$ ) was stirred at room temperature for $10 \mathrm{~h}$. The reaction mixture was passed through a Celite pad, and the volatiles were removed in vacuo. The residual solid was washed with hexane to give a red powder. Recrystallization from THF afforded red crystal. ${ }^{1} \mathrm{H}$ NMR $\left(400 \mathrm{MHz}, \mathrm{CDCl}_{3}\right) \delta 8.05(\mathrm{~m}, 2 \mathrm{H}), 7.65(\mathrm{~m}, 2 \mathrm{H})$, $5.64(\mathrm{~d}, J=2.3 \mathrm{~Hz}, 2 \mathrm{H}), 4.18(\mathrm{~s}), 1.38(\mathrm{~d}, J=13.7 \mathrm{~Hz}, 36 \mathrm{H}) ;{ }^{31} \mathrm{P}$ NMR $\left(162 \mathrm{MHz}, \mathrm{CDCl}_{3}\right) \delta 81.0(\mathrm{~d}, J=$ $152 \mathrm{~Hz}$ ), -143.6 (quin, $J=715 \mathrm{~Hz}$ ).

\section{Preparation of $(R, R)-4 b \cdot O T f$ According to the Stepwise Protocol.}

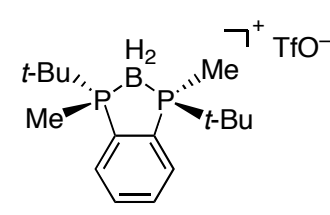

To a solution of (S)-tert-butyl(methyl)phosphine-borane $(65 \mathrm{mg}, 550 \mu \mathrm{mol})$ in benzene $(1 \mathrm{~mL})$ was slowly added trifluoromethanesulfonic acid $(48 \mu \mathrm{L}, 543 \mu \mathrm{mol})$ at room temperature. After $10 \mathrm{~min}$, the volatiles were removed under reduced pressure. A solution of $(R)-5(91.4 \mathrm{mg}, 273 \mu \mathrm{mol})$ in $\mathrm{CH}_{2} \mathrm{Cl}_{2}(1 \mathrm{~mL})$ was then added to the residue at room temperature under $\mathrm{N}_{2}$, and the mixture was stirred at intact temperature. After $36 \mathrm{~h}$, the volatiles were removed under reduced pressure, and the residue was subjected to column chromatography on silica gel eluting with $\mathrm{CHCl}_{3} / \mathrm{MeOH}(1 / 0$ to $10 / 1)$ to give int- $\mathbf{A}$ as a yellow solid $(110 \mathrm{mg})$. To a solution of int-A in THF $(2 \mathrm{~mL})$ was added $s$-BuLi $(181 \mu \mathrm{L}$ of $1.01 \mathrm{M}$ in cyclohexane $/ n$-hexane solution, $183 \mu \mathrm{mol}$ ) at $-78{ }^{\circ} \mathrm{C}$, and the mixture was stirred at $-40{ }^{\circ} \mathrm{C}$. After $24 \mathrm{~h}$, the reaction mixture was diluted with water and extracted with $\mathrm{CHCl}_{3}$. The combined extract was dried over $\mathrm{Na}_{2} \mathrm{SO}_{4}$, and was exposed to UV under air at room temperature for $1 \mathrm{~h}$. The mixture was passed through a Celite pad and concentrated under reduced pressure, and the residue was subjected to column chromatography on silica gel (chloroform/methanol $=1 / 0$ to $10 / 1)$ to give $(R, R)-\mathbf{4 b} \cdot \mathrm{OTf}$ as a white solid (70 mg, 58\%). ${ }^{1} \mathrm{H}$ NMR (400 MHz, $\left.\mathrm{CDCl}_{3}\right) \delta 8.14(\mathrm{~m}, 2 \mathrm{H}), 7.97(\mathrm{~m}, 2 \mathrm{H}), 1.94(\mathrm{~d}, \mathrm{~J}=11.0 \mathrm{~Hz}, 6 \mathrm{H}), 1.23(\mathrm{~d}, J=$ $16.5 \mathrm{~Hz}, 18 \mathrm{H})) ;{ }^{13} \mathrm{C}$ NMR $\left(100 \mathrm{MHz}, \mathrm{CDCl}_{3}\right) \delta 134.8(\mathrm{~s}), 134.1(\mathrm{t}, J=42 \mathrm{~Hz}), 133(\mathrm{t}, J=7.6 \mathrm{~Hz}), 121(\mathrm{~d}, J$ $=318 \mathrm{~Hz}), 30.5(\mathrm{~m}), 24.7(\mathrm{~s}), 6.53(\mathrm{~m}) ;{ }^{31} \mathrm{P}$ NMR $\left(162 \mathrm{MHz}, \mathrm{CDCl}_{3}\right) \delta 39.8(\mathrm{~d}, J=95 \mathrm{~Hz}) ; \mathrm{IR}(\mathrm{KBr}) 2971$, $2468,2424,2342,1471,1280,1260,1152,1030,895,770,637 \mathrm{~cm}^{-1} ;[\alpha]_{\mathrm{D}}^{22.5}=-28.8\left(c 0.510, \mathrm{CHCl}_{3}\right)$; HRMS (ESI): $m / z$ Calcd. for $\mathrm{C}_{33} \mathrm{H}_{60} \mathrm{~B}_{2} \mathrm{~F}_{3} \mathrm{O}_{3} \mathrm{P}_{4} \mathrm{~S}[2 \mathrm{M}-\mathrm{OTf}]^{+}$739.33518. Found 739.33359. The enantiomeric excess was determined to be $>99 \%(99 \%$ de) by chiral HPLC analysis after converted into $\mathbf{4 b} \cdot \mathbf{I}$ by treatment with sat. aqueous $\mathrm{NaI}$ solution.

\section{Typical Procedure for the Pd-catalyzed Hydroesterification of Unsaturated Compounds}

A $50 \mathrm{~mL}$ glass autoclave equipped with a pressure gauge and a stirring bar was charged with $\mathrm{Pd}(\mathrm{OAc})_{2}$ $(1.12 \mathrm{mg}, 5.0 \mu \mathrm{mol})$ and $\mathbf{1 a}(2.33 \mathrm{mg}, 6.25 \mu \mathrm{mol})$. After the atmosphere was replaced with nitrogen, substrate $(2.5 \mathrm{mmol})$, toluene $(1 \mathrm{~mL})$, and methanesulfonic acid $(38.5 \mu \mathrm{mol}, 2.5 \mu \mathrm{L})$ in ethanol $(400 \mu \mathrm{L})$ was added to the reaction vessel. The autoclave was then immersed in a dryice/methanol bath and nitrogen atmosphere was replaced with carbon monoxide, pressurized to $6 \mathrm{~atm}$, and then heated in a preheated oil bath at $80{ }^{\circ} \mathrm{C}$. The mixture was left for $12 \mathrm{~h}$ under vigorous stirring, and after being allowed to ambient temperature, it was filtered through silica gel with ethyl acetate elution. After concentration under reduced pressure, the yield was determined by ${ }^{1} \mathrm{H}$ NMR. 


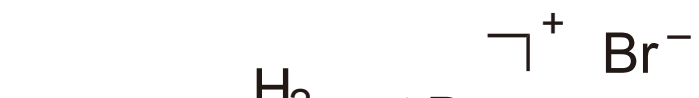

$t-\mathrm{Bu}$, $\mathrm{H} \quad \mathrm{H}$

$3 a \cdot \mathrm{Br},{ }^{1} \mathrm{H}$ in $\mathrm{CDCl}_{3}(400 \mathrm{MHz})$

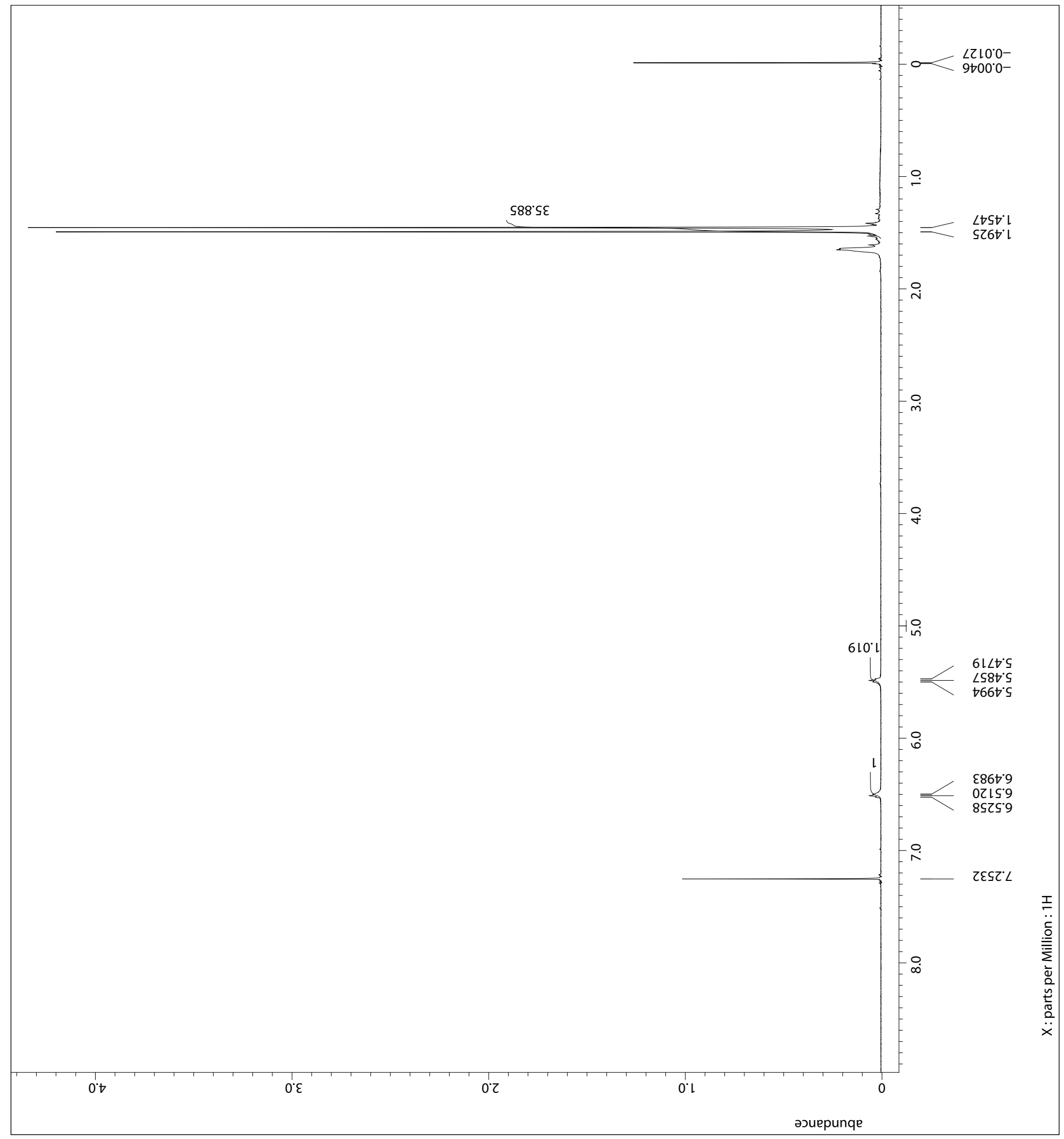




$$
\begin{aligned}
& \mathrm{H}_{2} ᄀ^{+} \mathrm{Br}^{-} \\
& t-\mathrm{Bu}=\mathrm{H}_{\mathrm{H}}^{t-\mathrm{Bu}}{ }_{\mathrm{H}}{ }^{\mathrm{B}-\mathrm{Bu}} \quad 3 \mathrm{a} \cdot \mathrm{Br},{ }^{13} \mathrm{C} \text { in } \mathrm{CDCl}_{3}(100 \mathrm{MHz})
\end{aligned}
$$

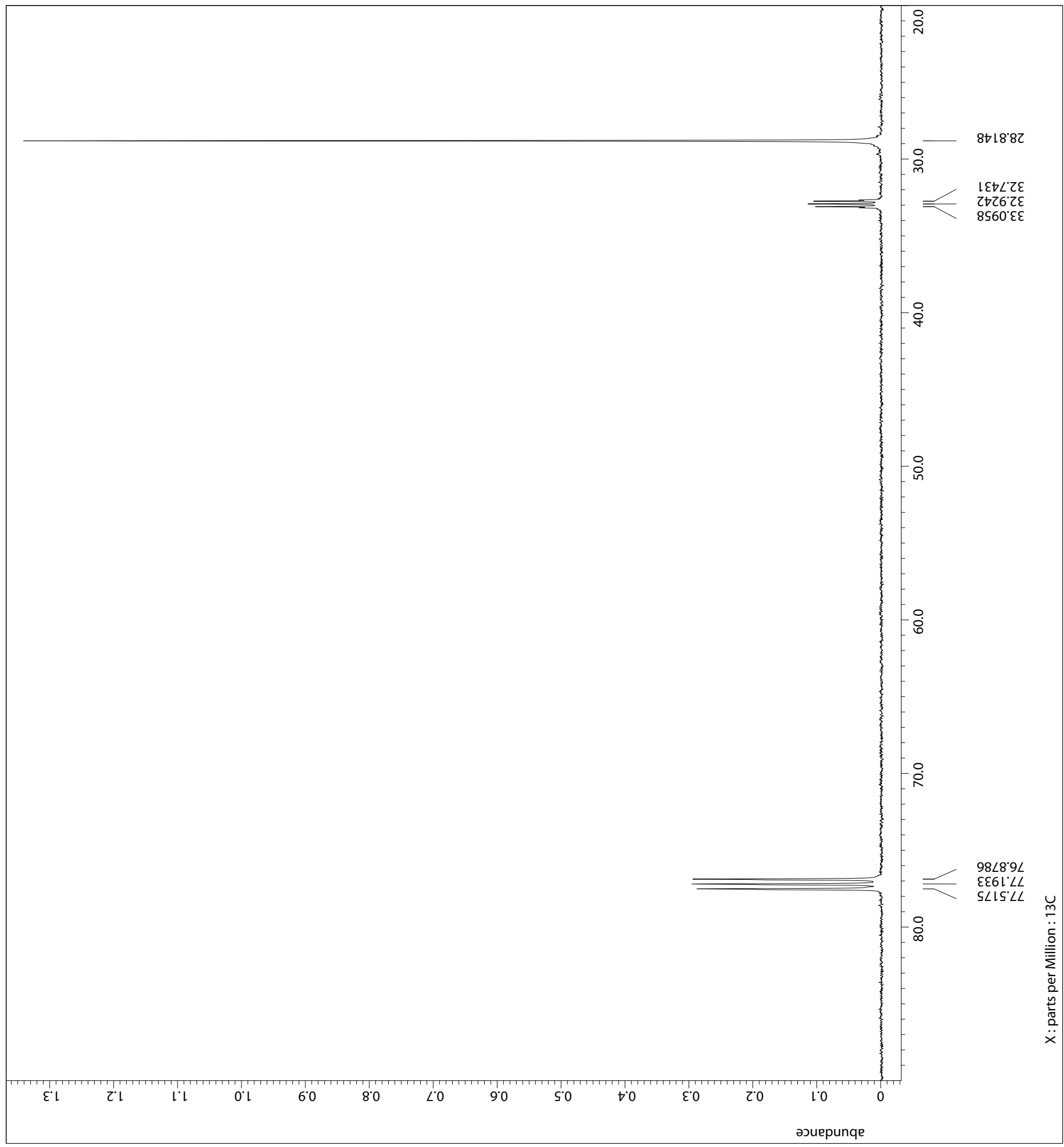


$\neg^{+} \mathrm{Br}^{-} \quad$ Supporting Information

$t-\mathrm{Bu} \quad \mathrm{H}_{2} \quad t-\mathrm{Bu}$

$t$-Bur ${ }_{\mathrm{H}}{ }_{\mathrm{H}}{ }^{-\mathrm{B}} t-\mathrm{Bu} \quad 3 \mathrm{~B} \cdot \mathrm{Br},{ }^{31} \mathrm{P}$ in $\mathrm{CDCl}_{3}(162 \mathrm{MHz})$

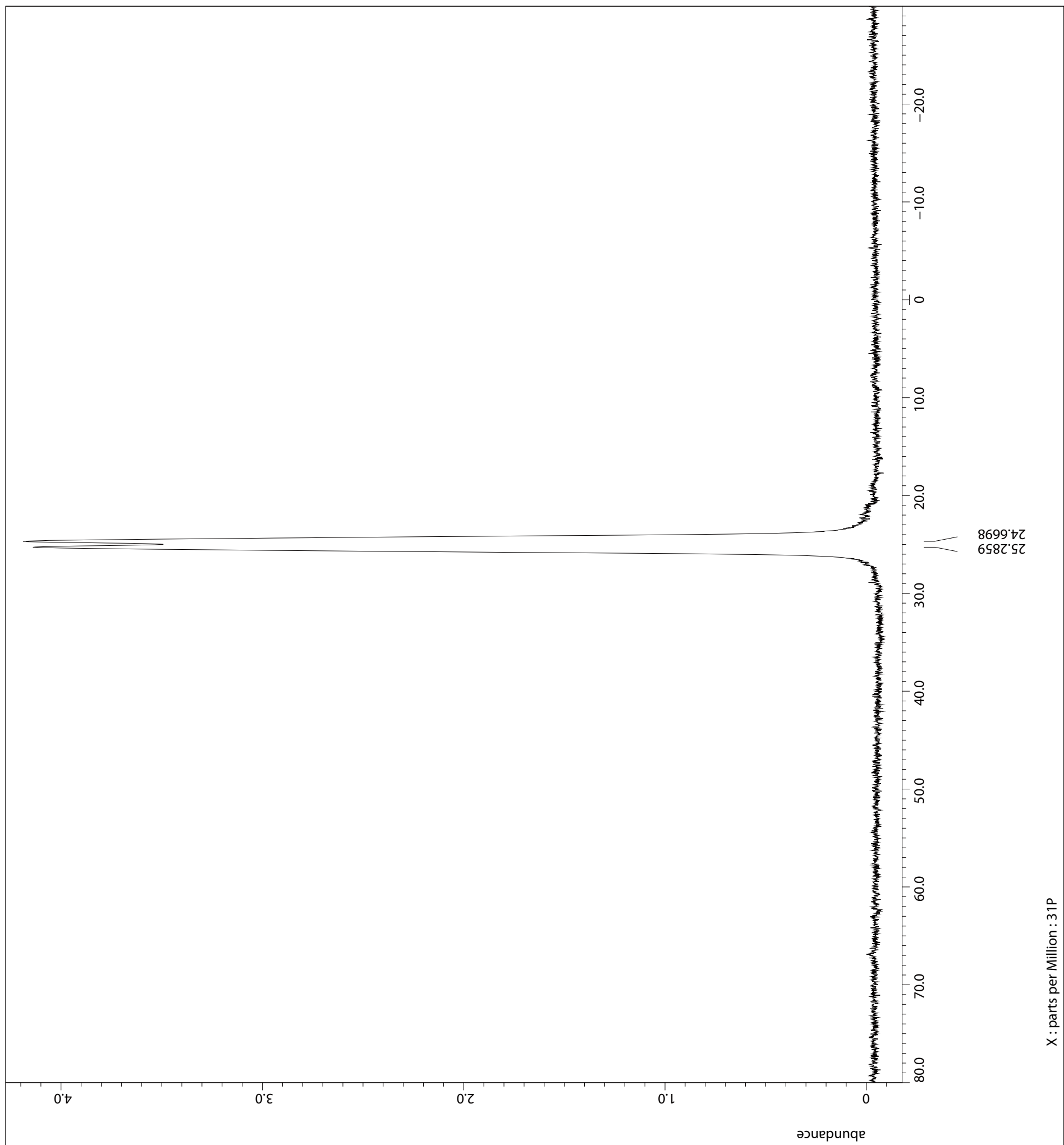


$t-\mathrm{Bu}$ "

$7^{+} \mathrm{I}^{-}$

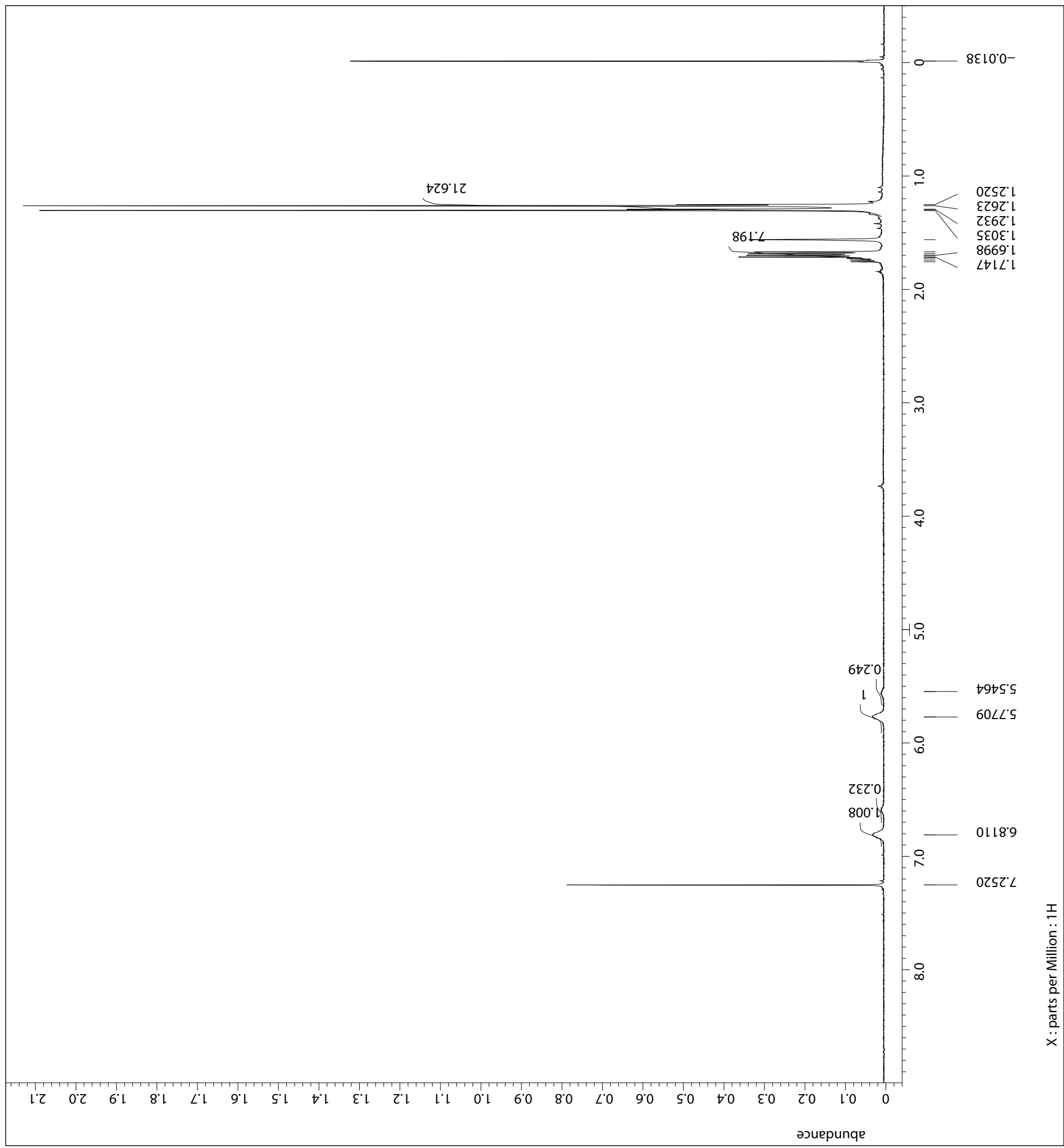




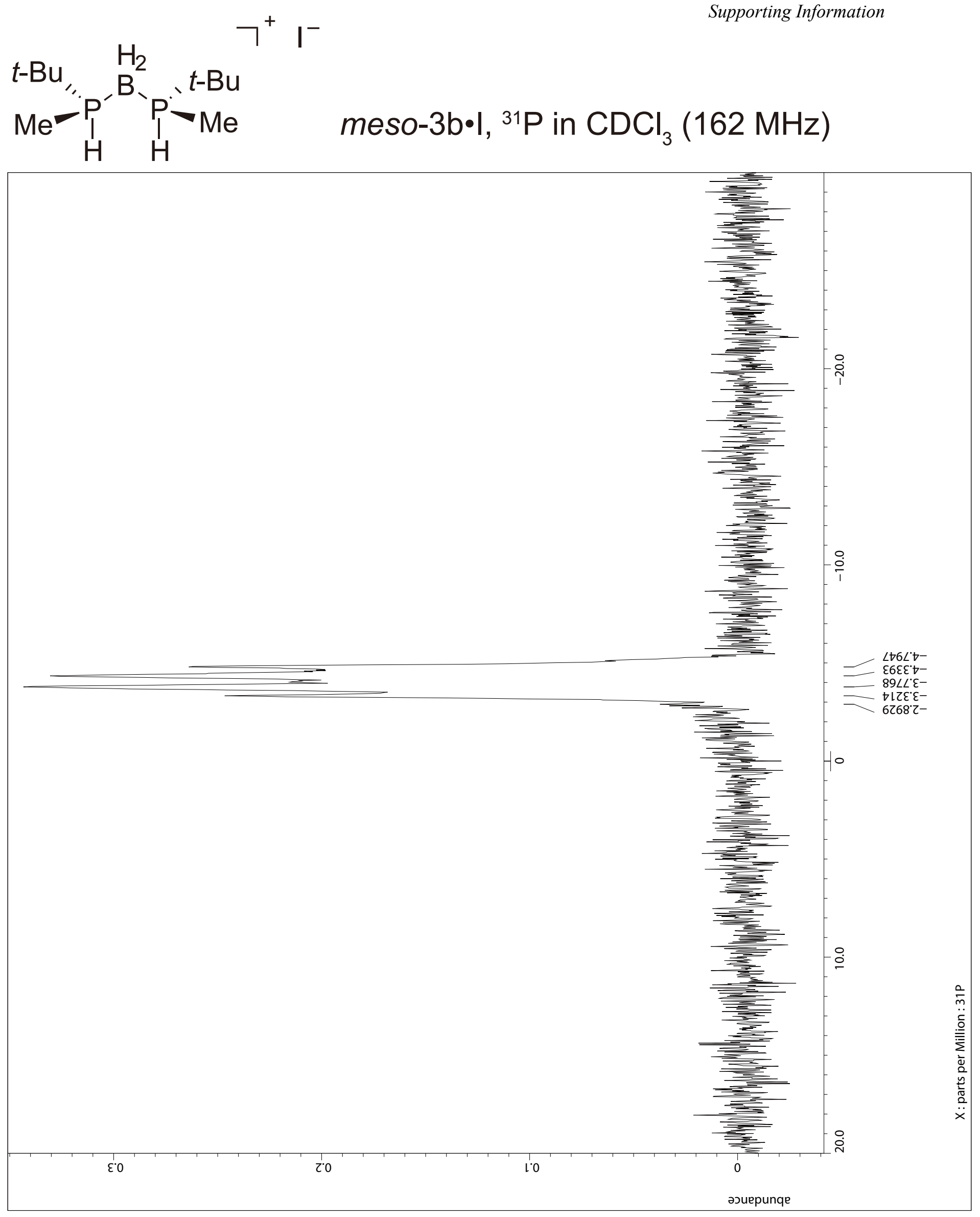




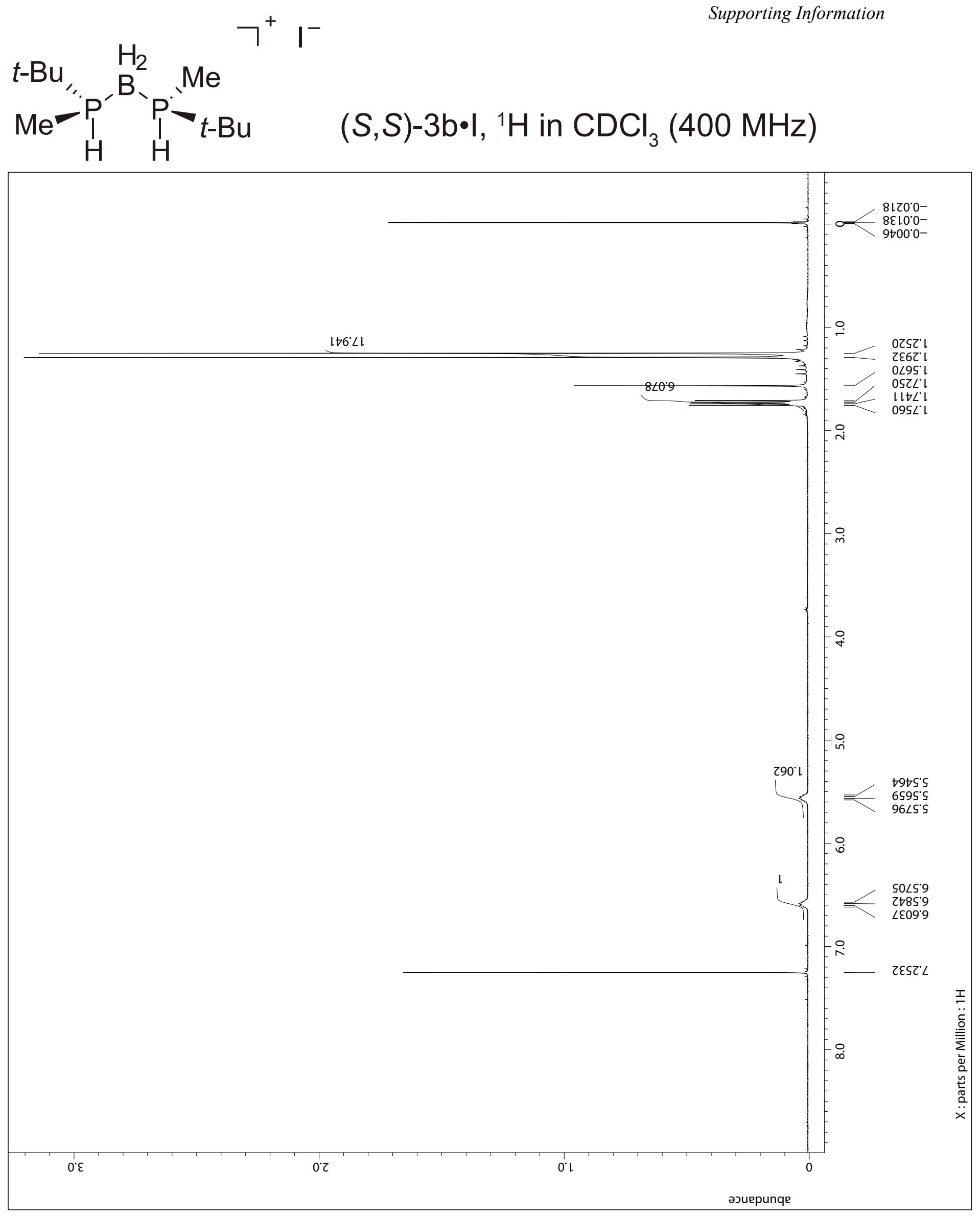




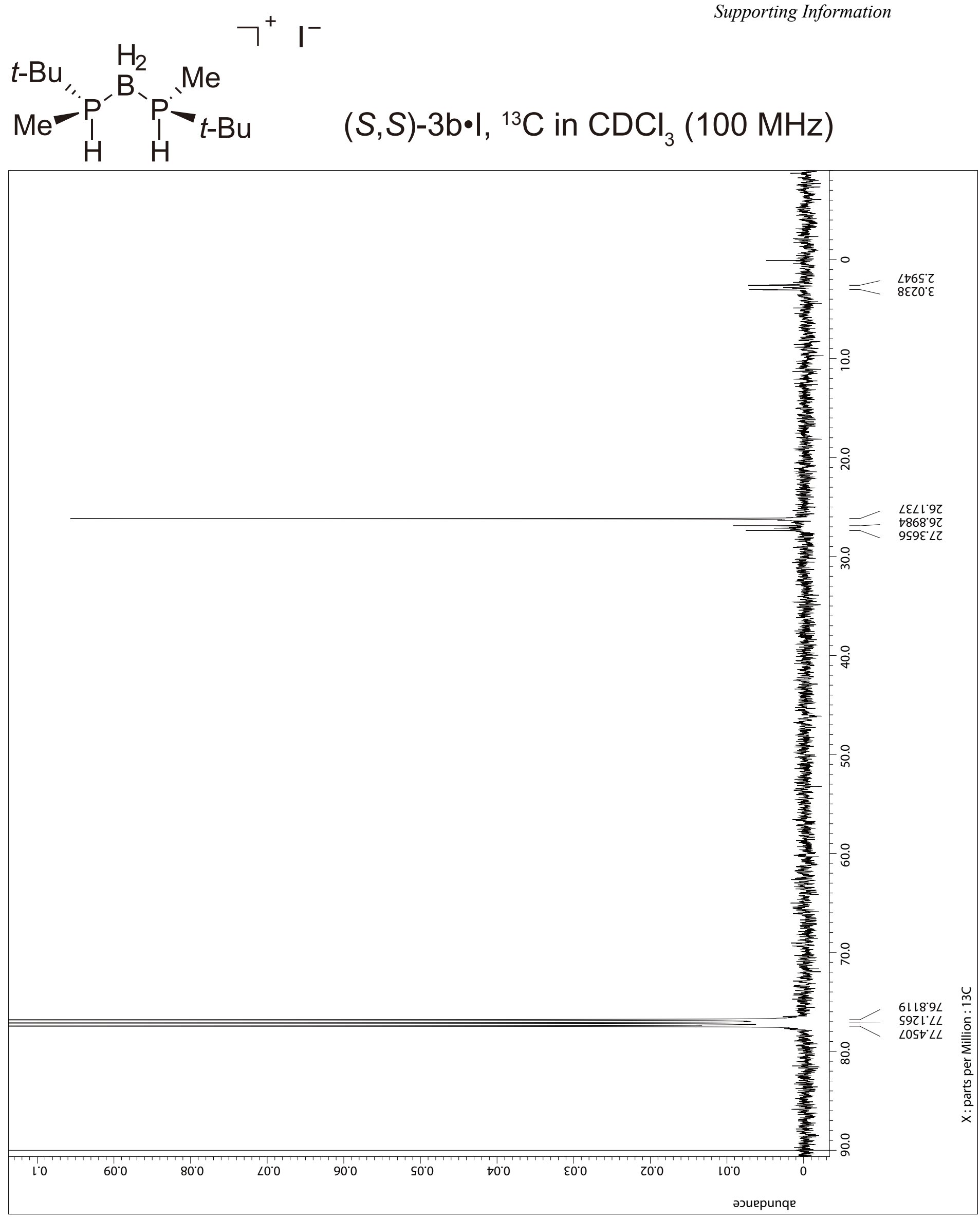




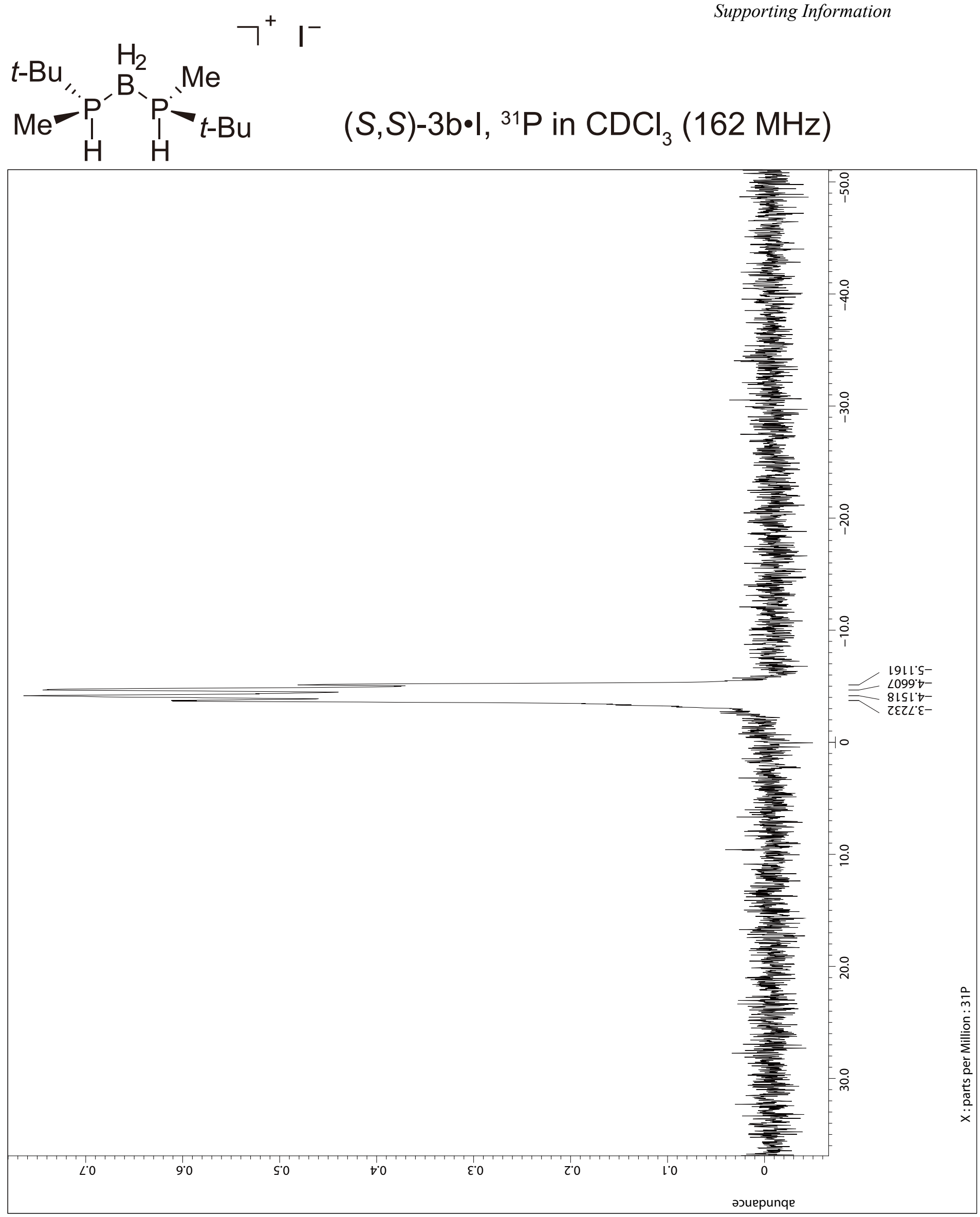




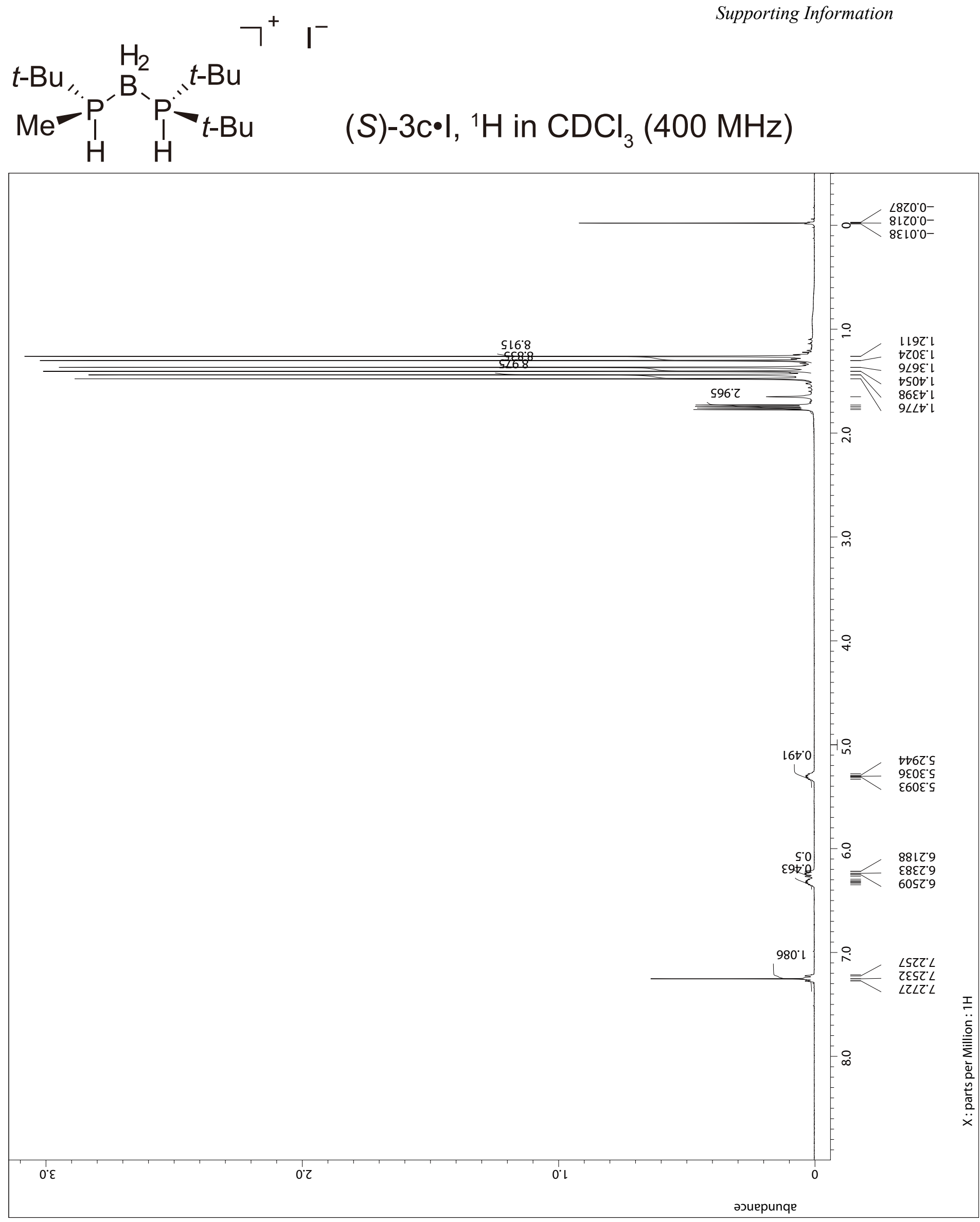




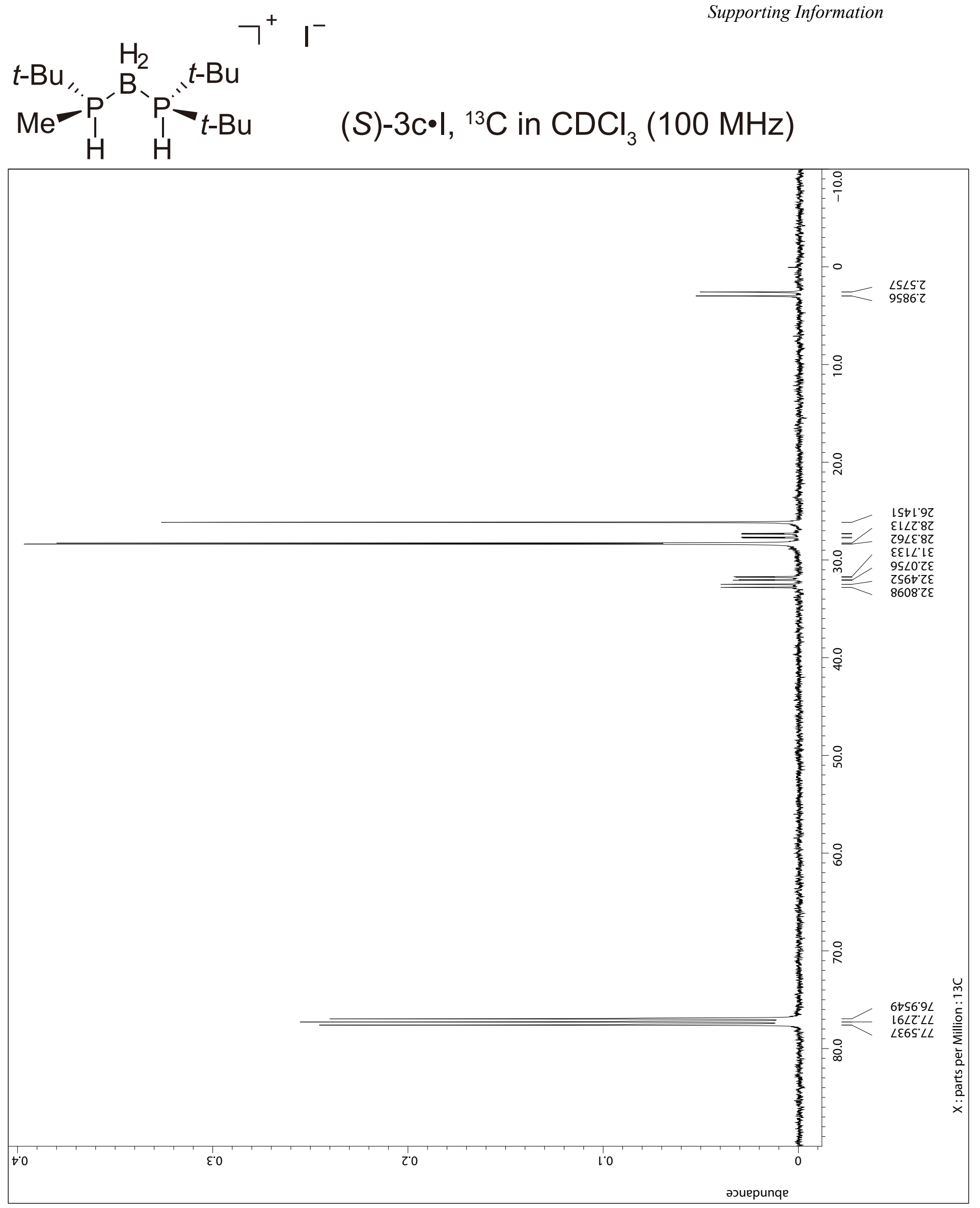




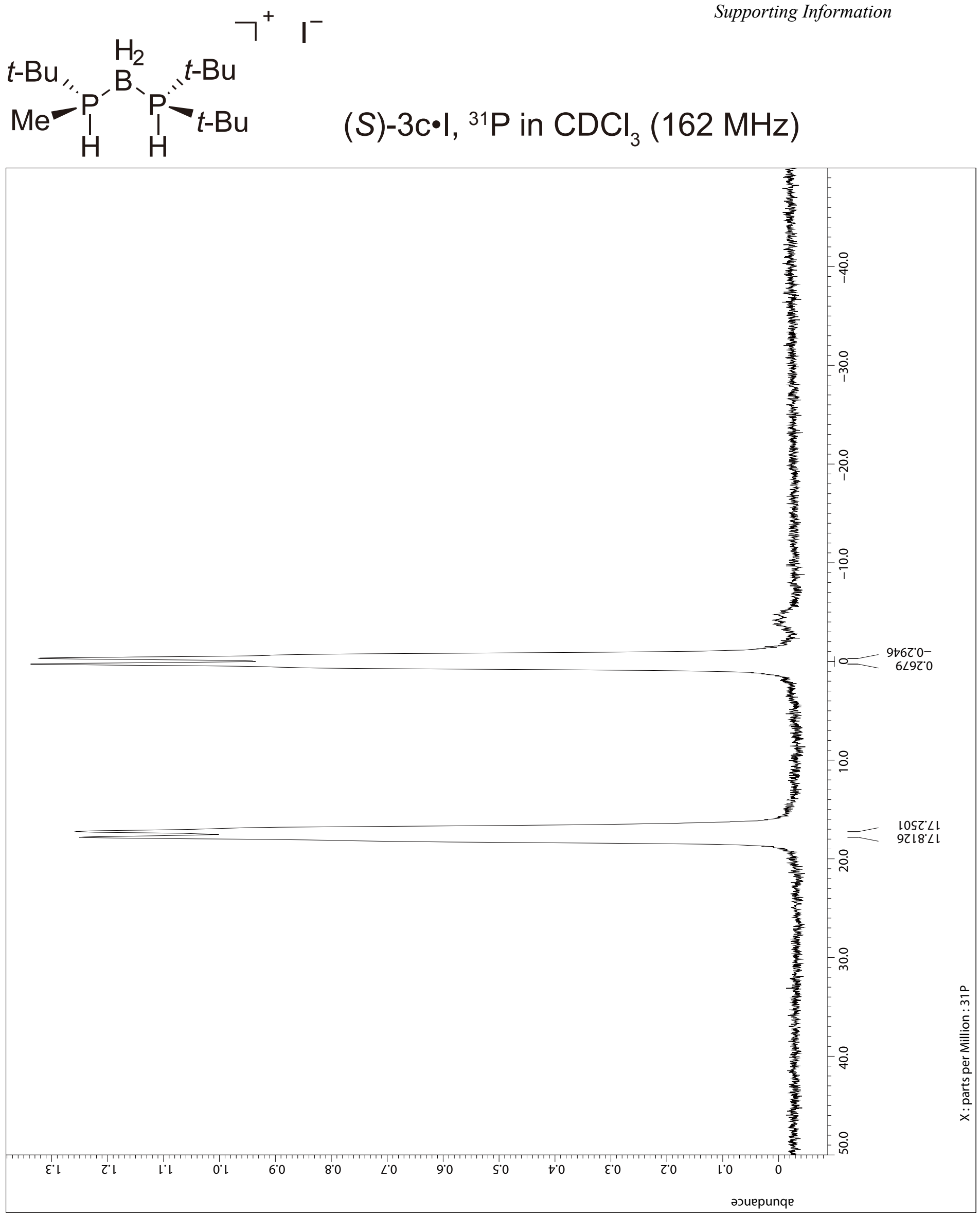




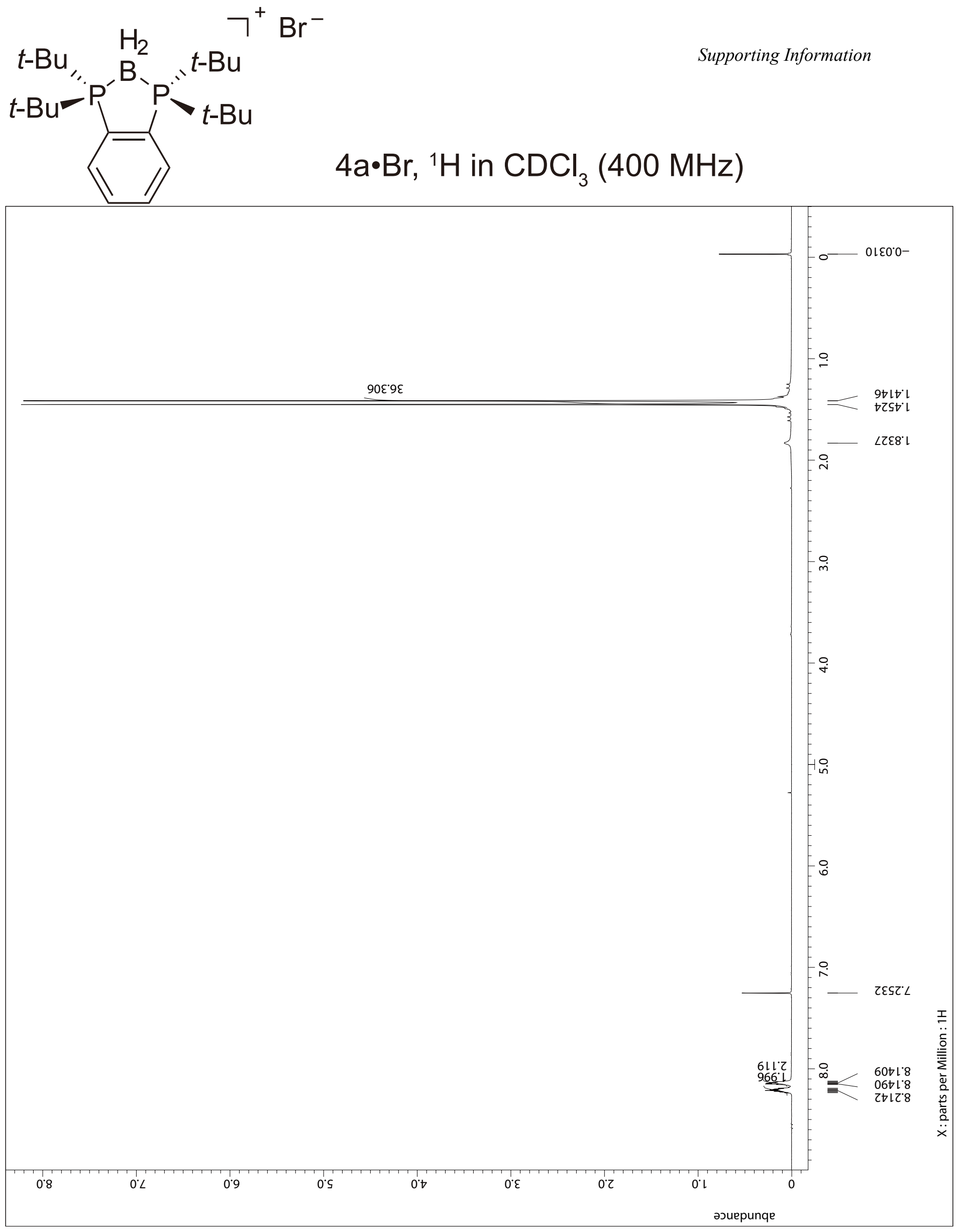




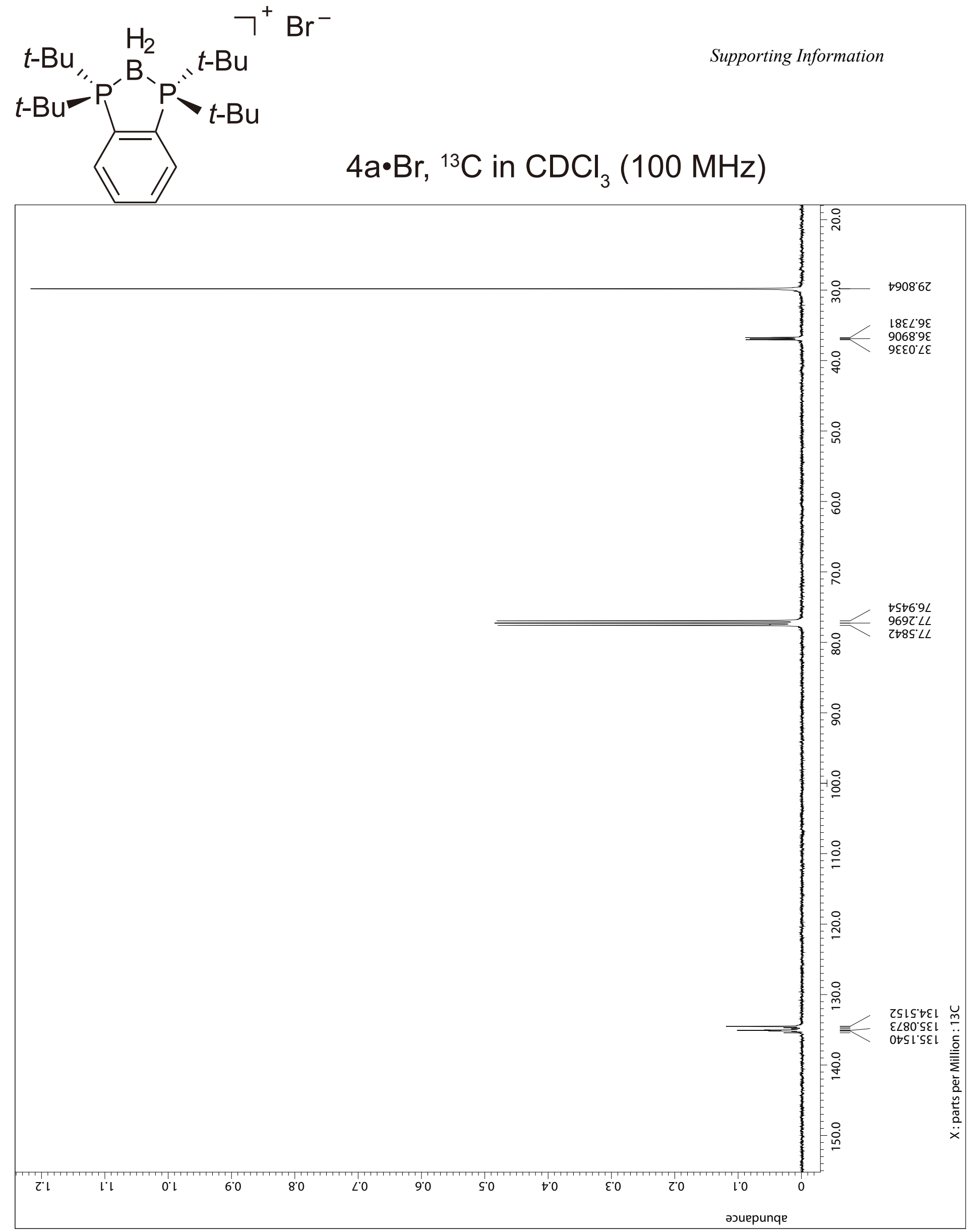




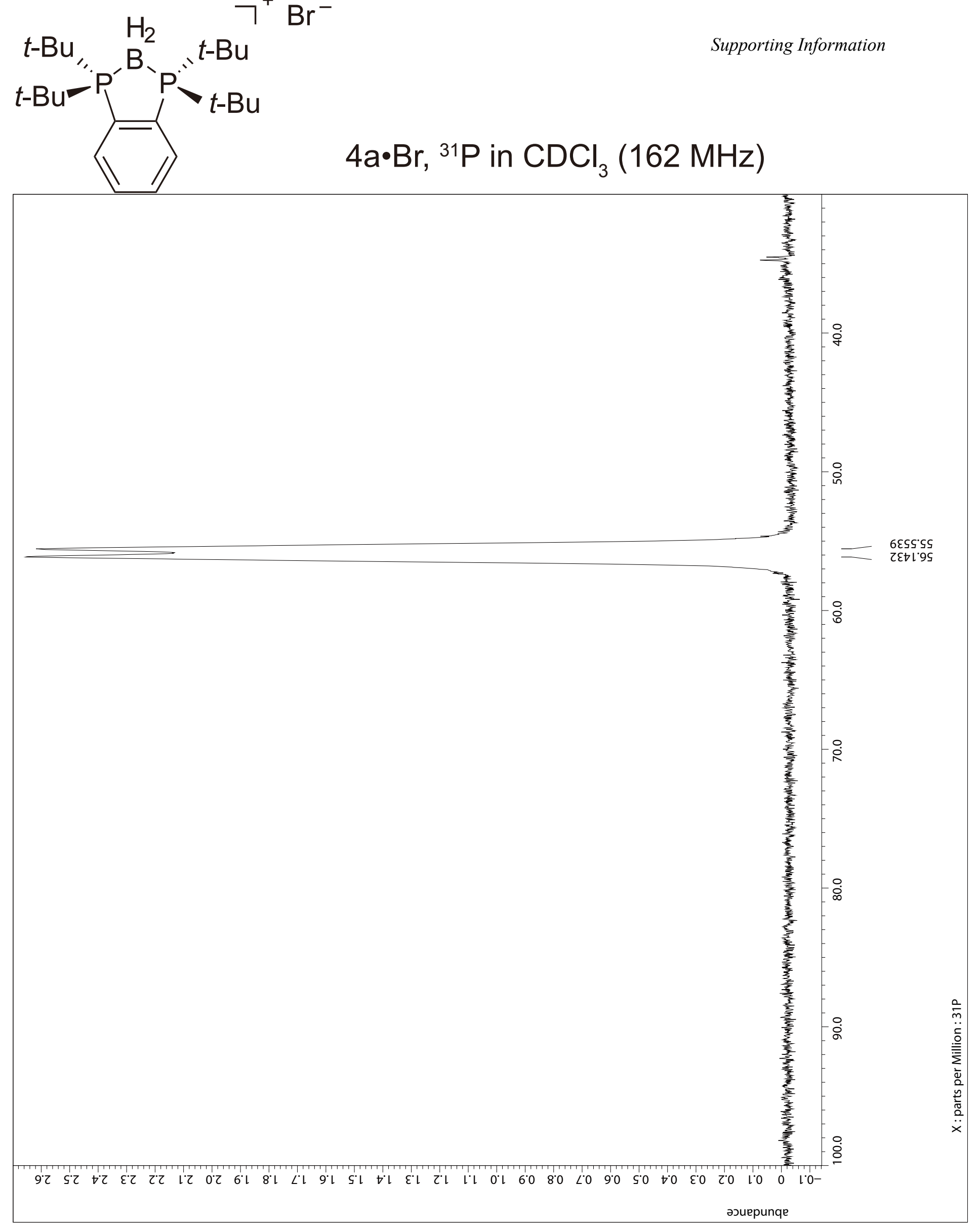




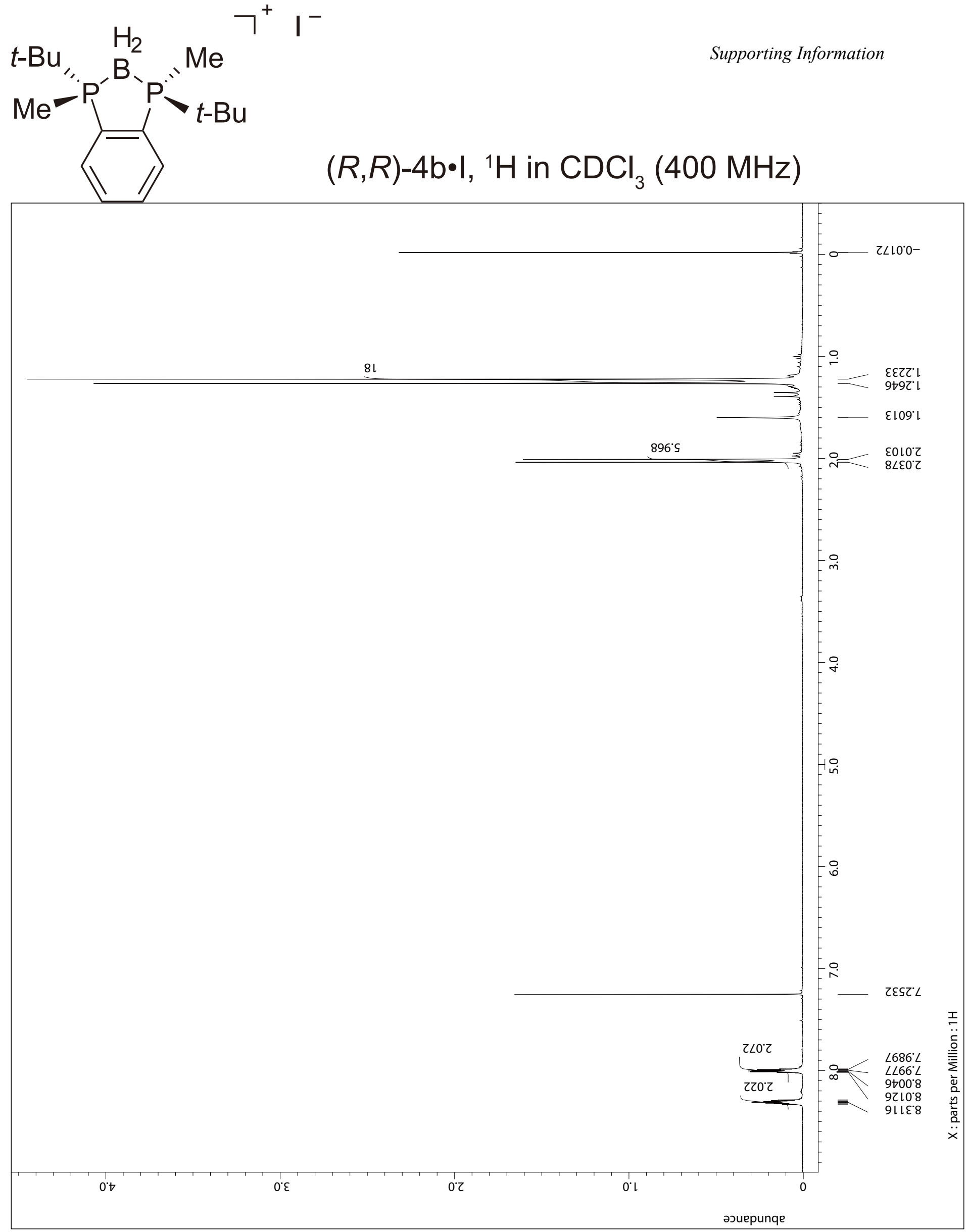


t-Bu $\quad \mathrm{H}_{2} \quad \neg^{+} \mathrm{I}^{-}$<smiles>CC(C)(C)[Pb]1(C)[B]P(C)(C)(C(C)(C)C)c2ccccc21</smiles>

$(R, R)-4 \mathrm{~b} \bullet \mid,{ }^{13} \mathrm{C}$ in $\mathrm{CDCl}_{3}(100 \mathrm{MHz})$

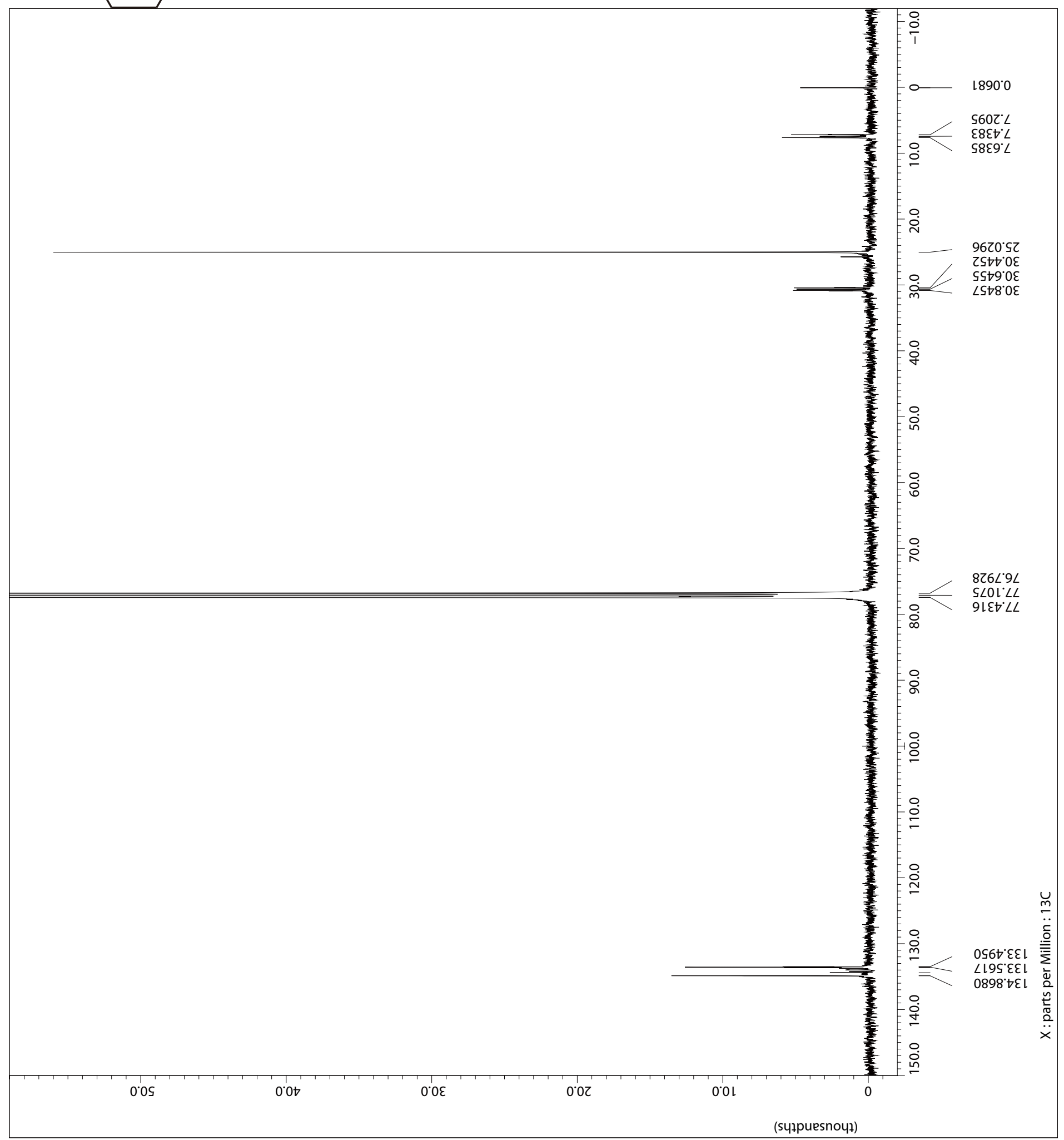


$\mathrm{H}_{2} \neg^{+} \mathrm{I}^{-}$

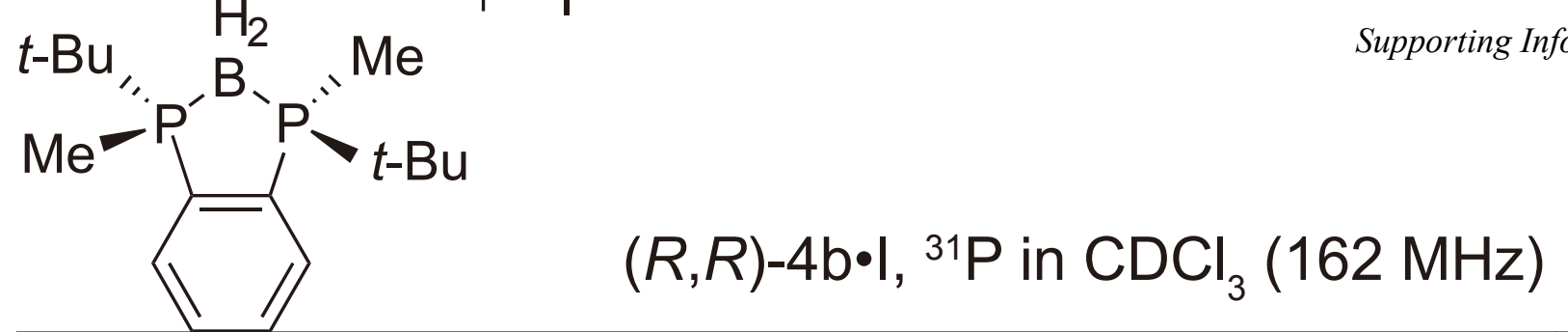

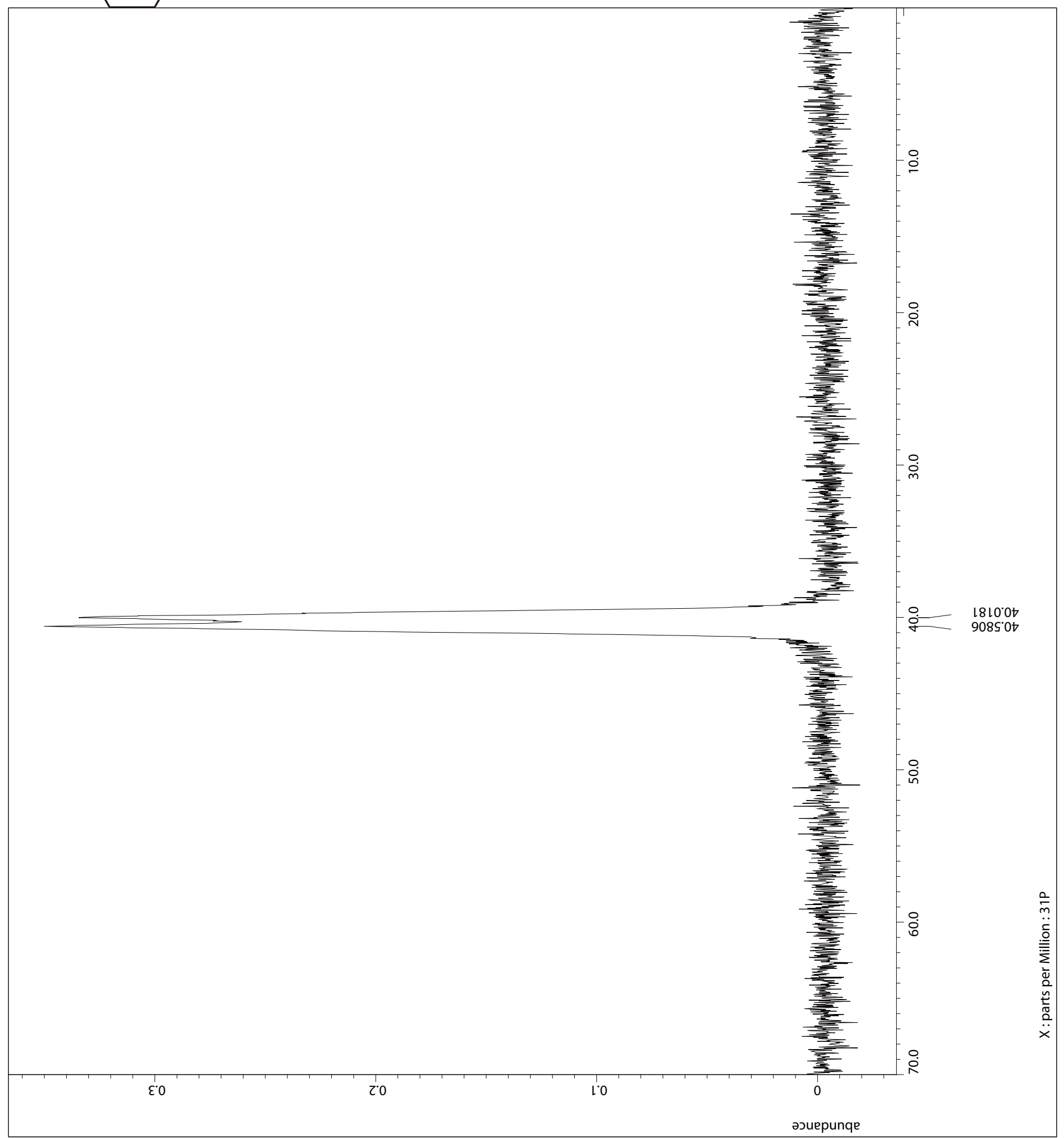


$\mathrm{H}_{2} \quad \neg^{+} \mathrm{I}^{-}$
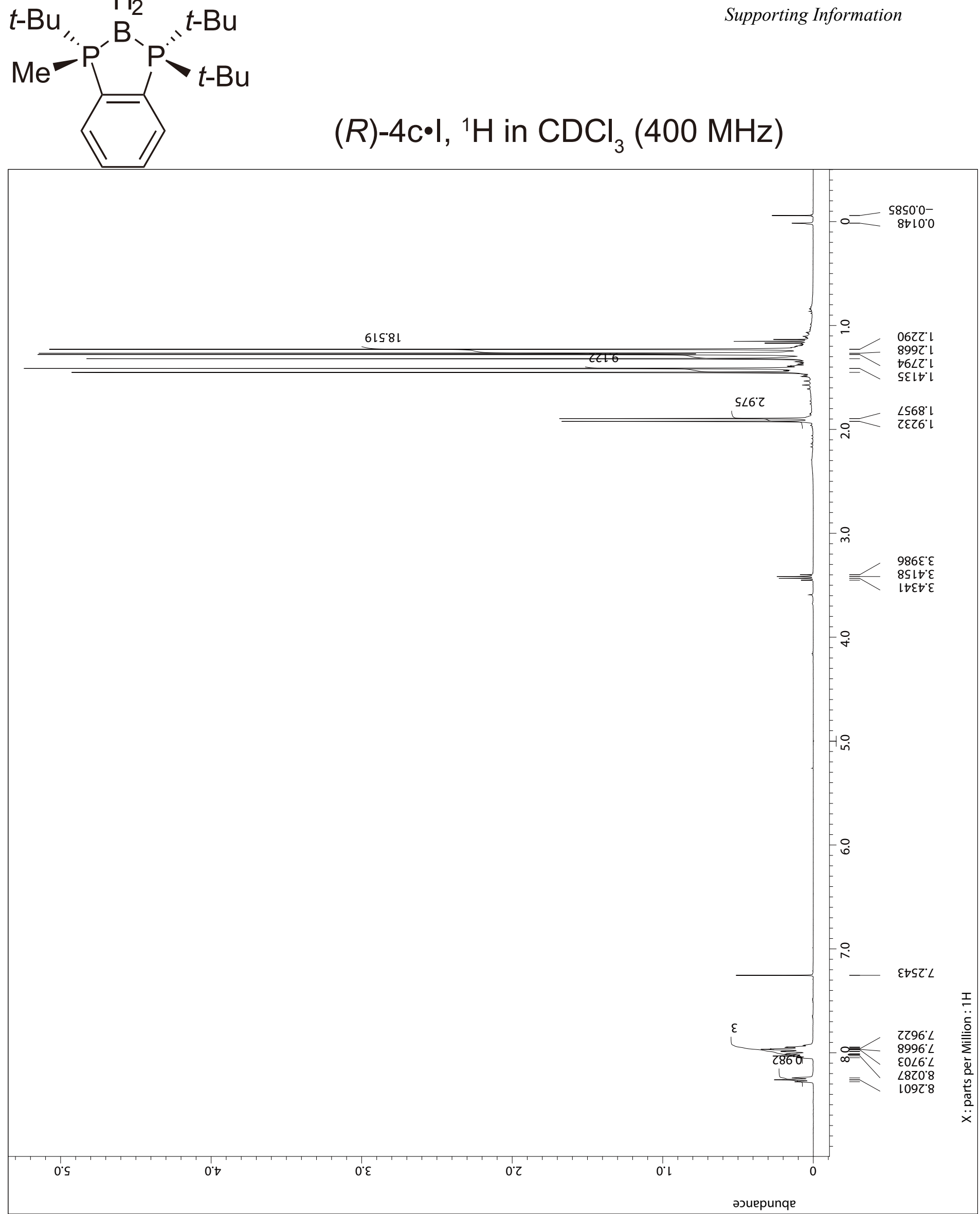


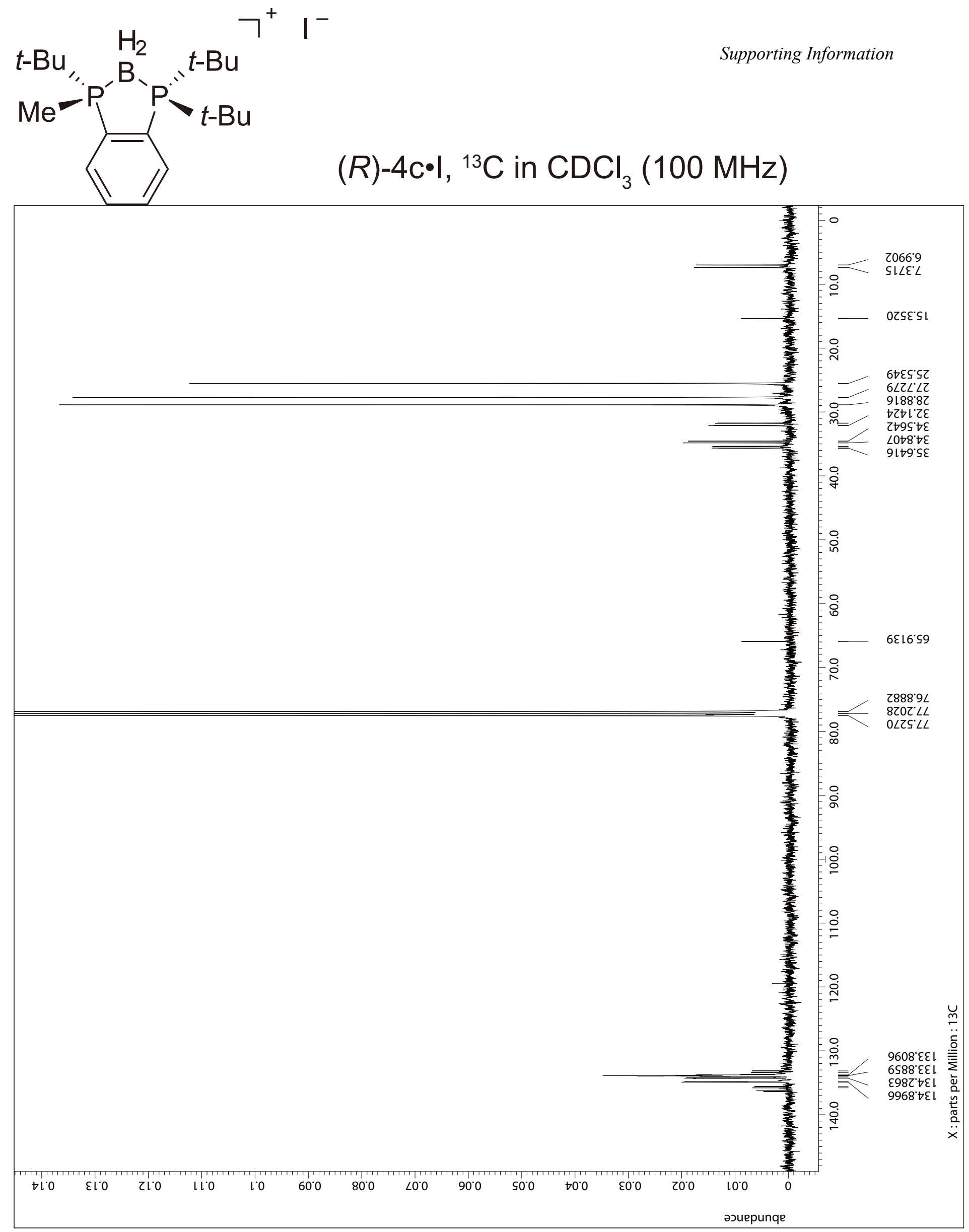


$\rightarrow-\mathrm{H}_{2} \quad 7^{+} \mathrm{I}^{-}$
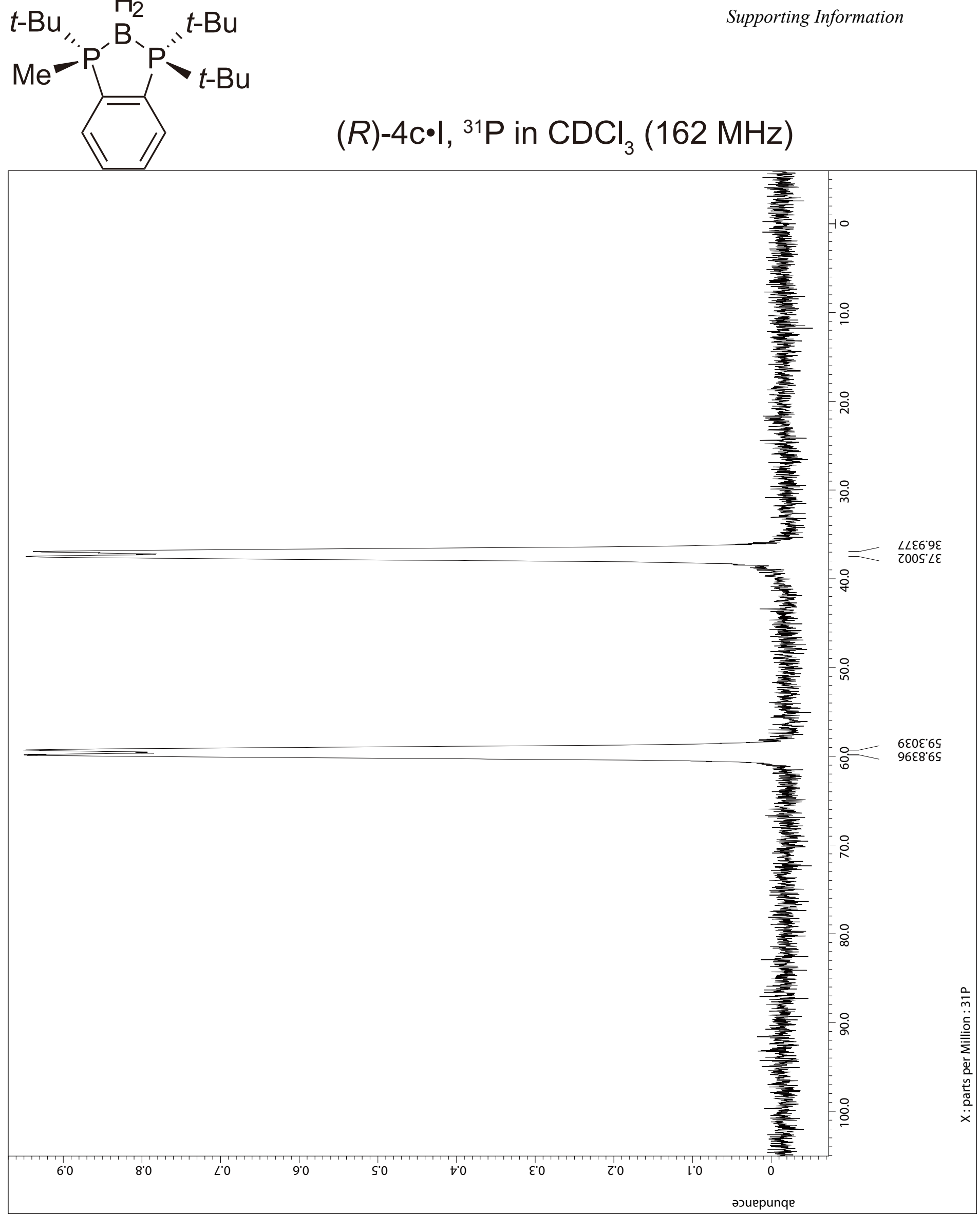


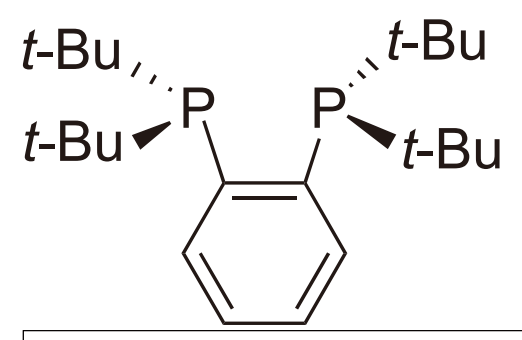

\section{1a, ${ }^{1} \mathrm{H}$ in $\mathrm{CDCl}_{3}(400 \mathrm{MHz})$}

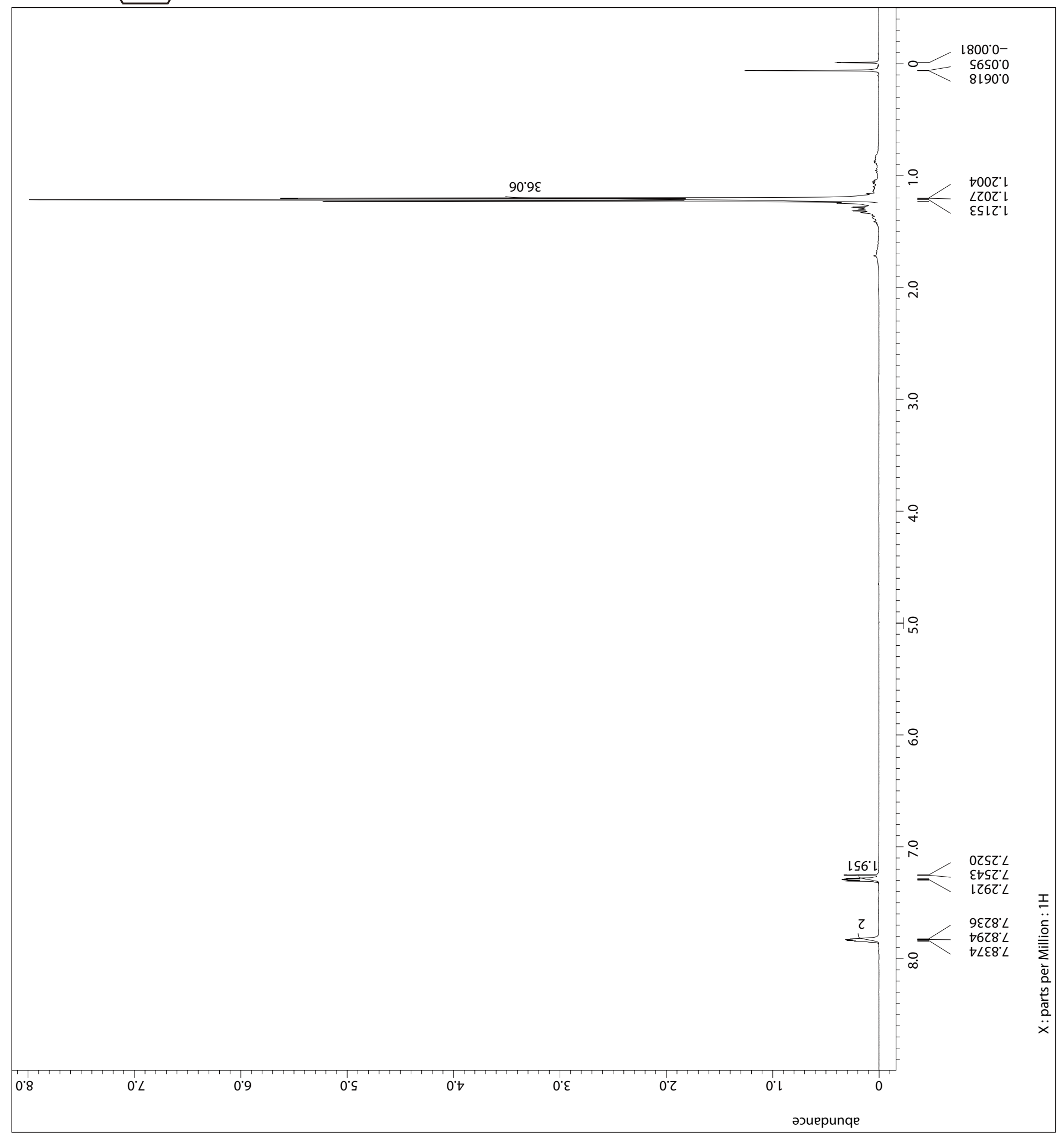




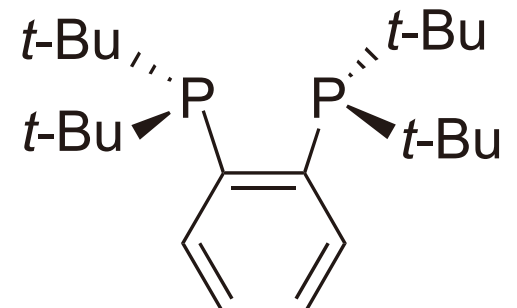

\section{$1 \mathrm{a},{ }^{31} \mathrm{P}$ in $\mathrm{CDCl}_{3}(162 \mathrm{MHz})$}

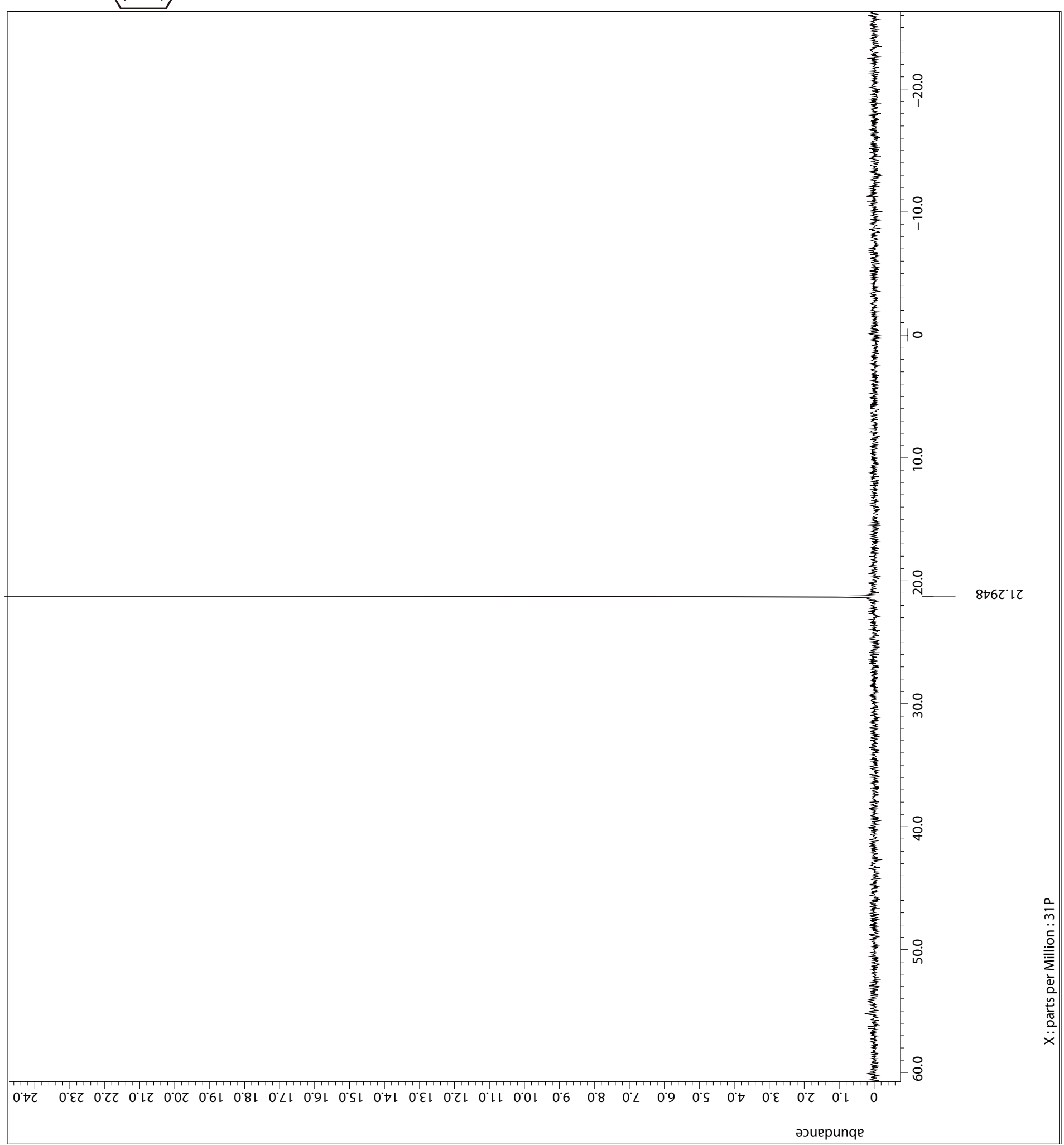




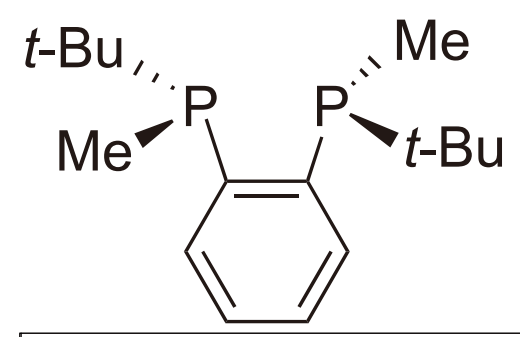

\section{1b, ${ }^{1} \mathrm{H}$ in $\mathrm{CDCl}_{3}(400 \mathrm{MHz})$}

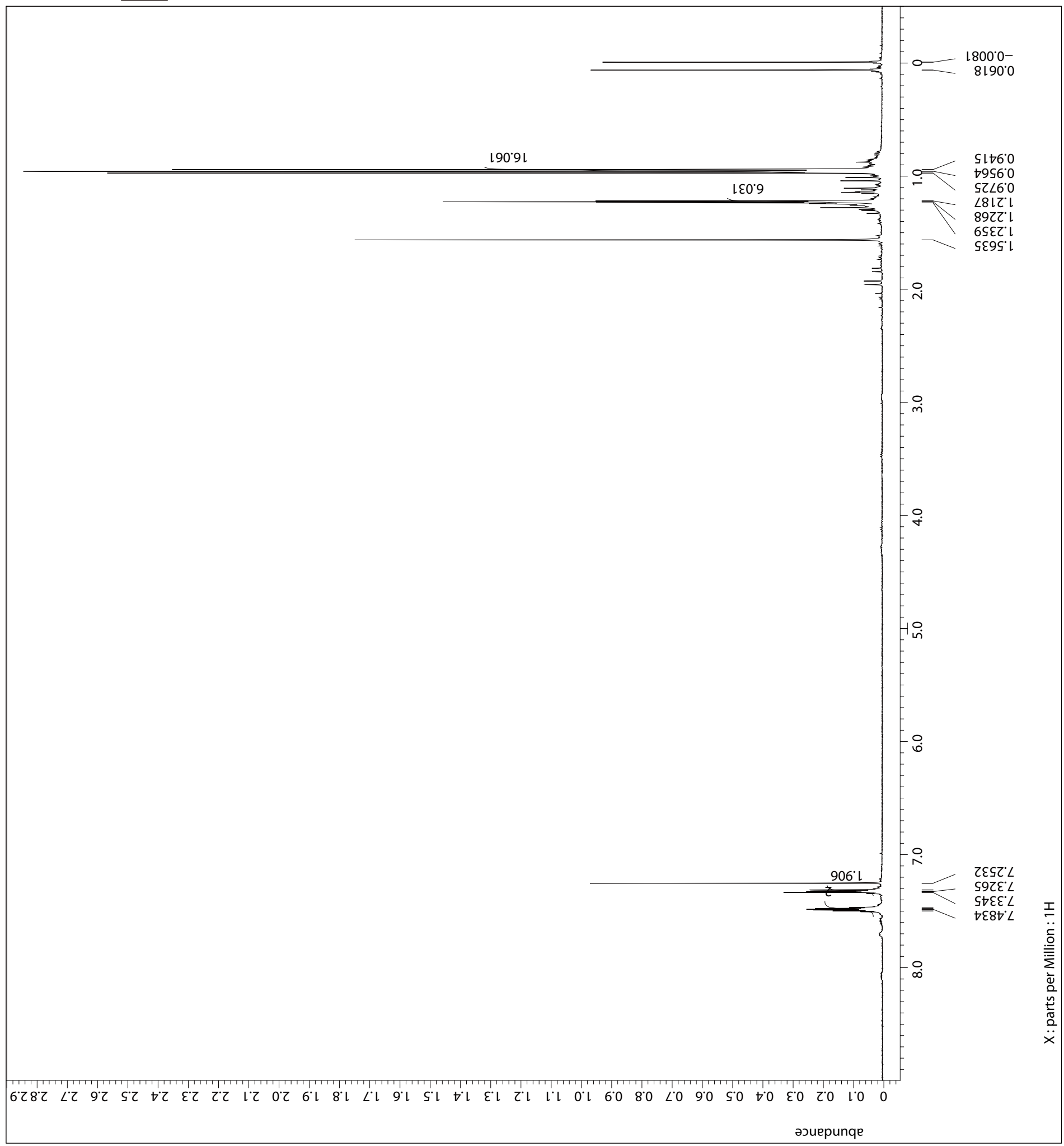




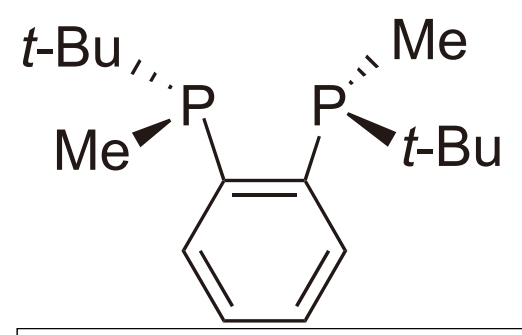

1b, ${ }^{31} \mathrm{P}$ in $\mathrm{CDCl}_{3}(162 \mathrm{MHz})$

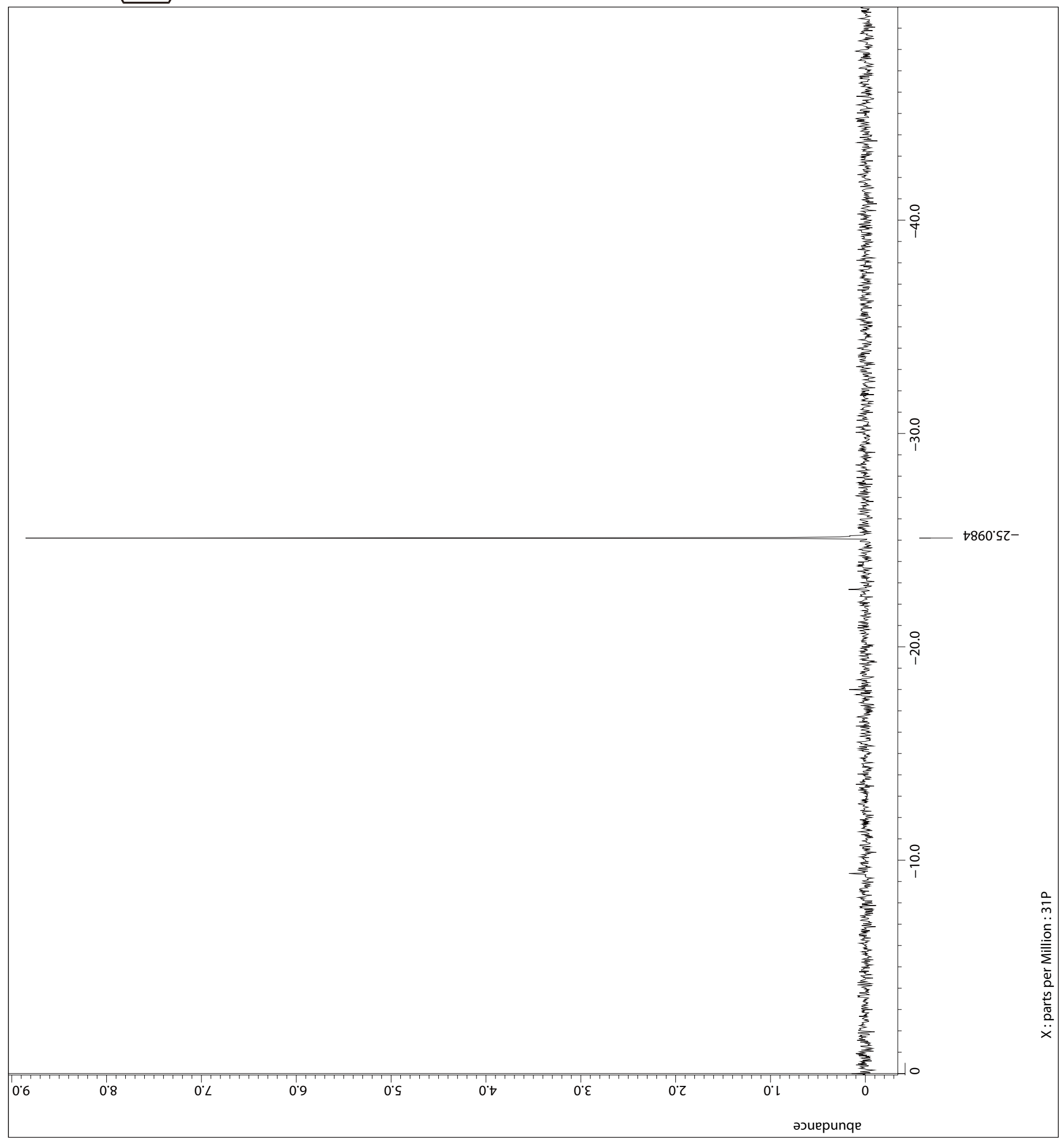



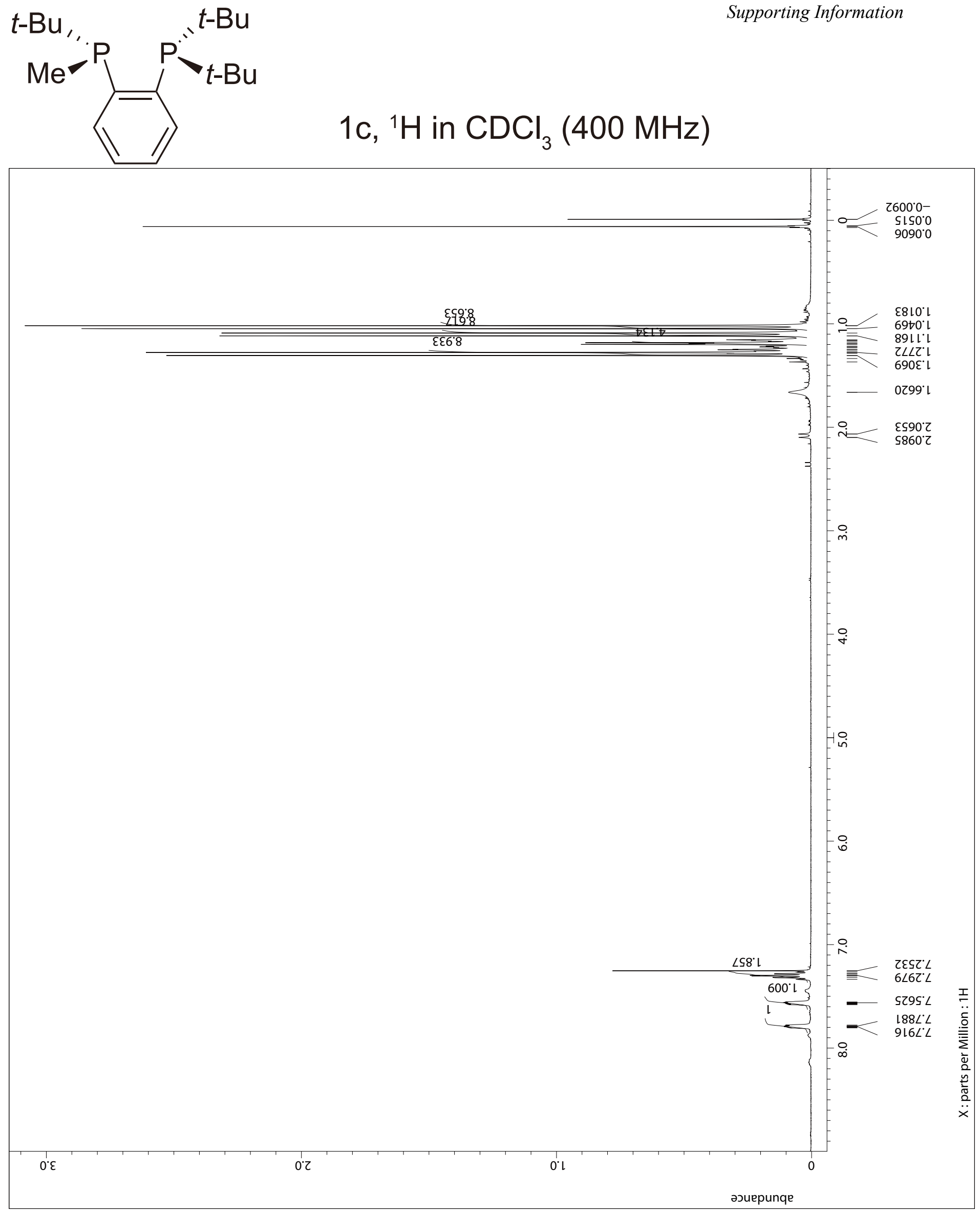


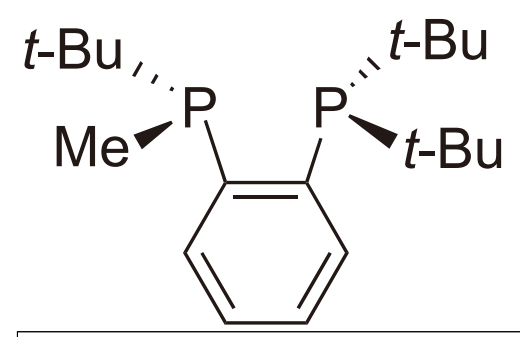

\section{1c, ${ }^{31} \mathrm{P}$ in $\mathrm{CDCl}_{3}(162 \mathrm{MHz})$}

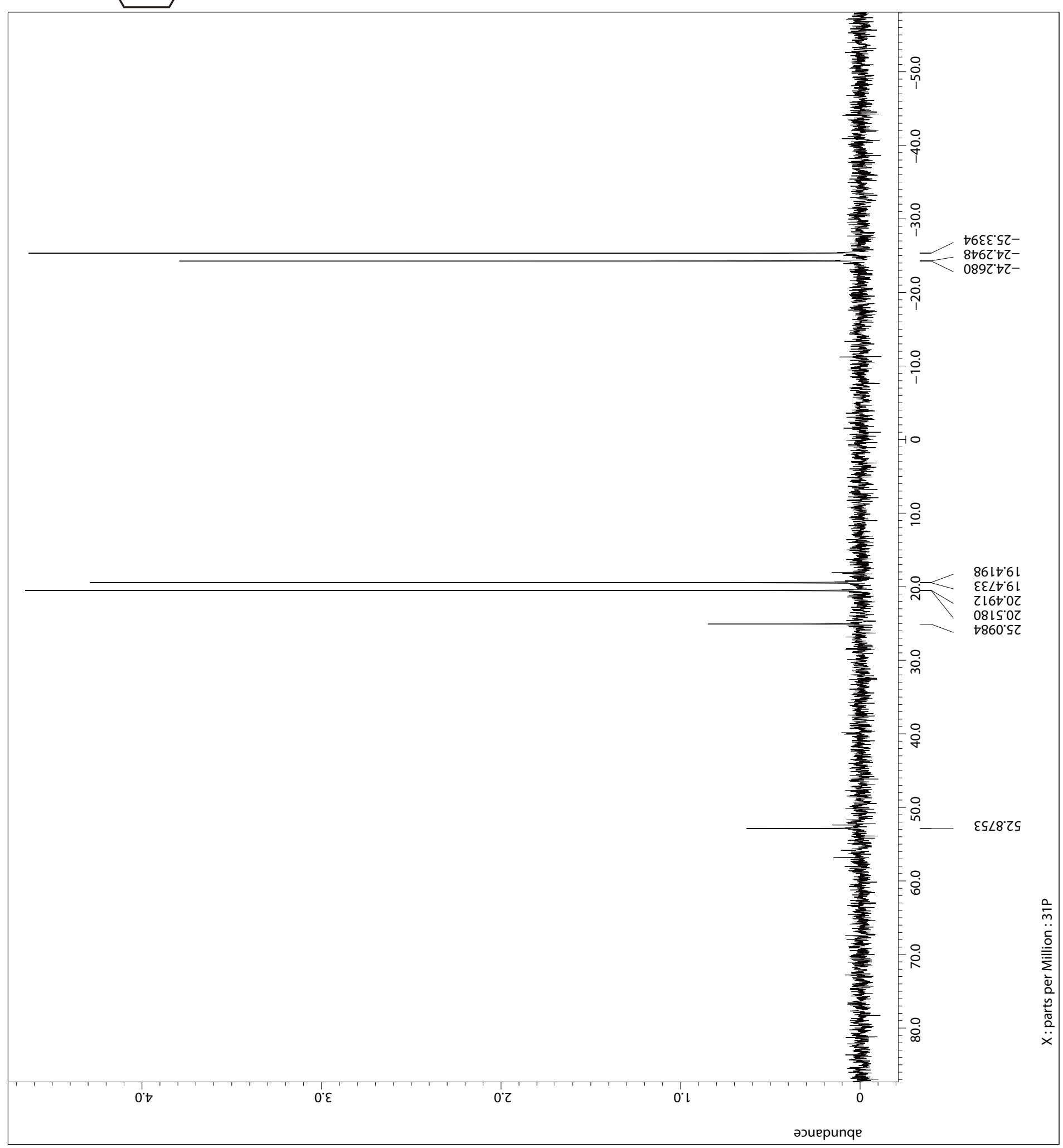




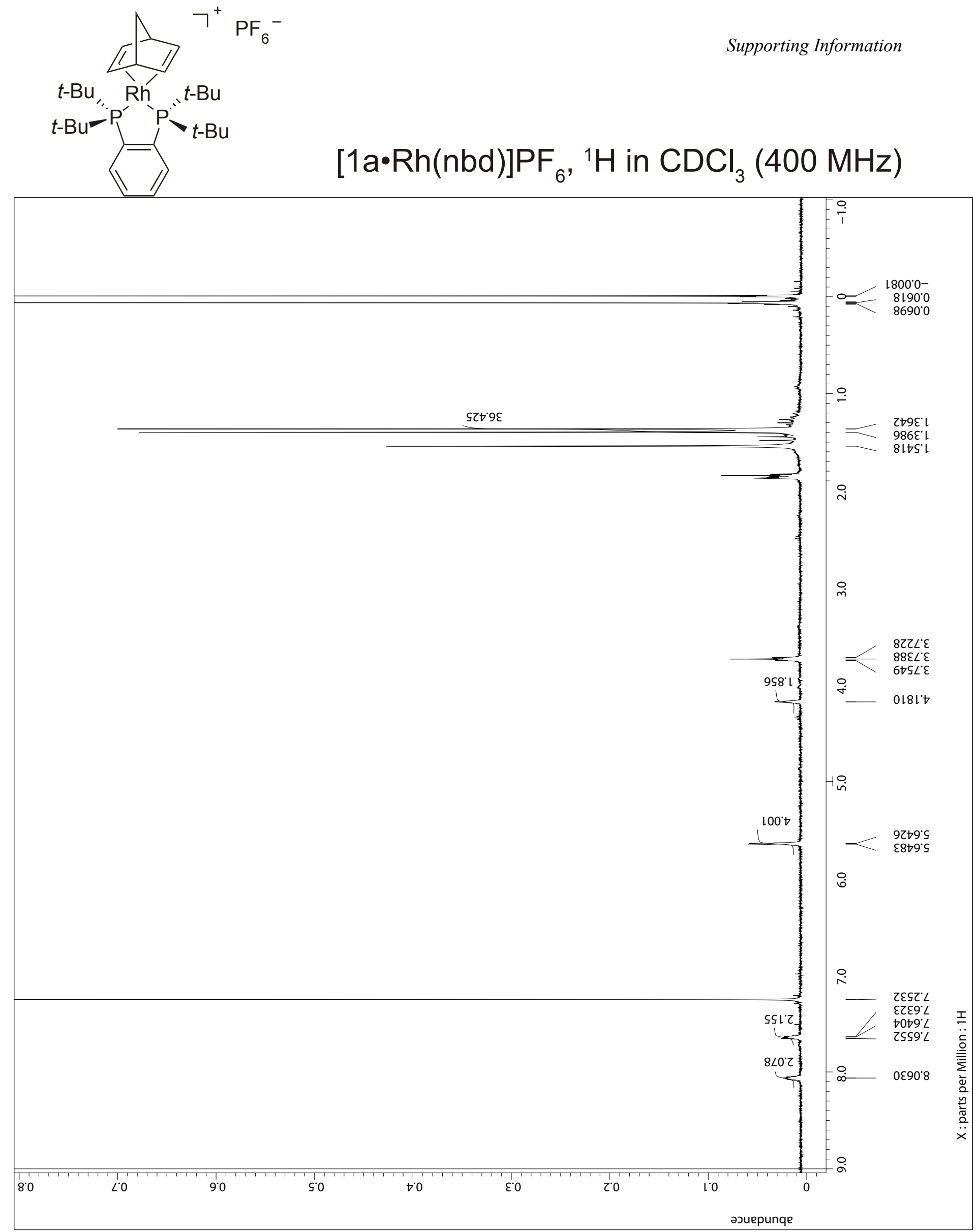




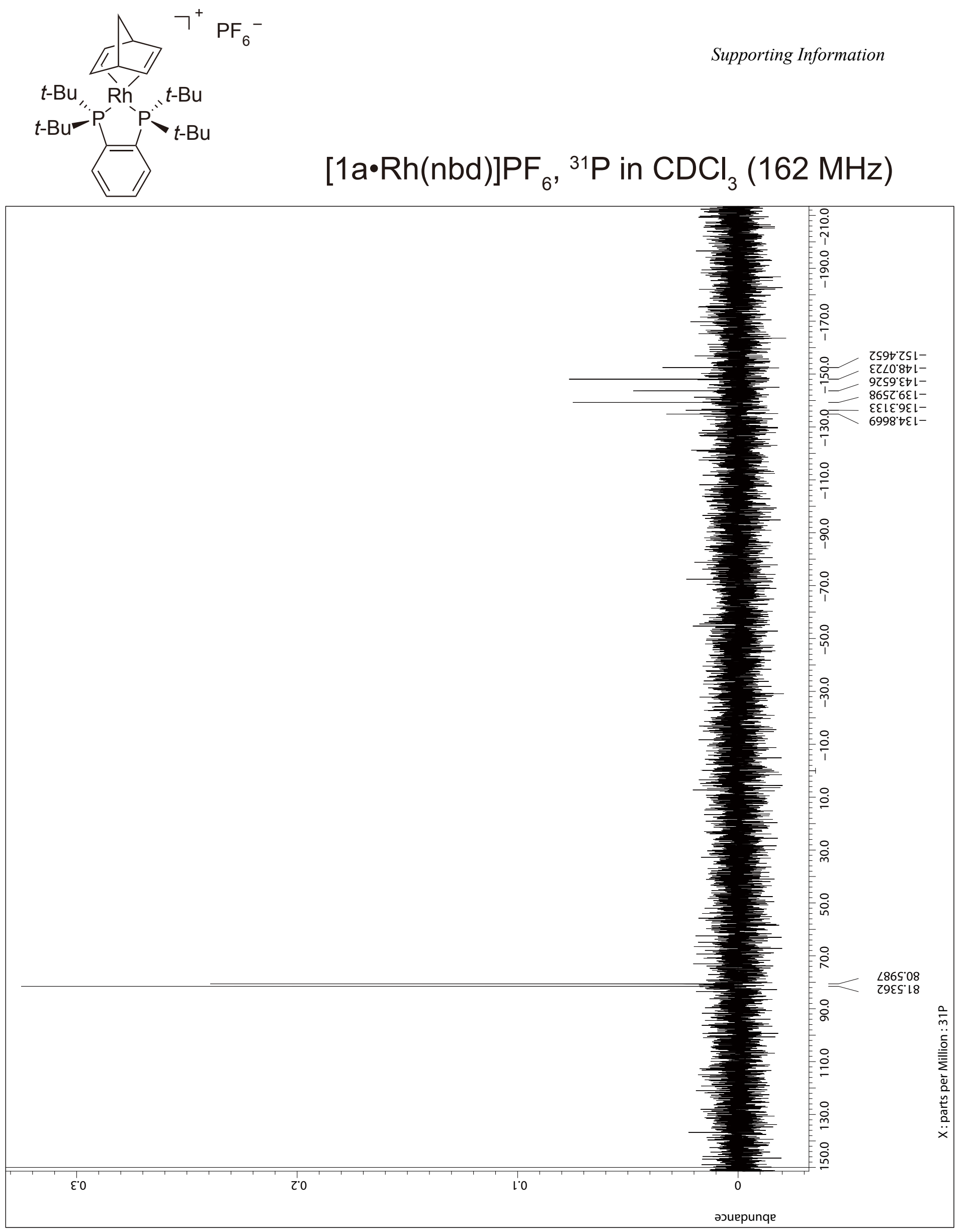




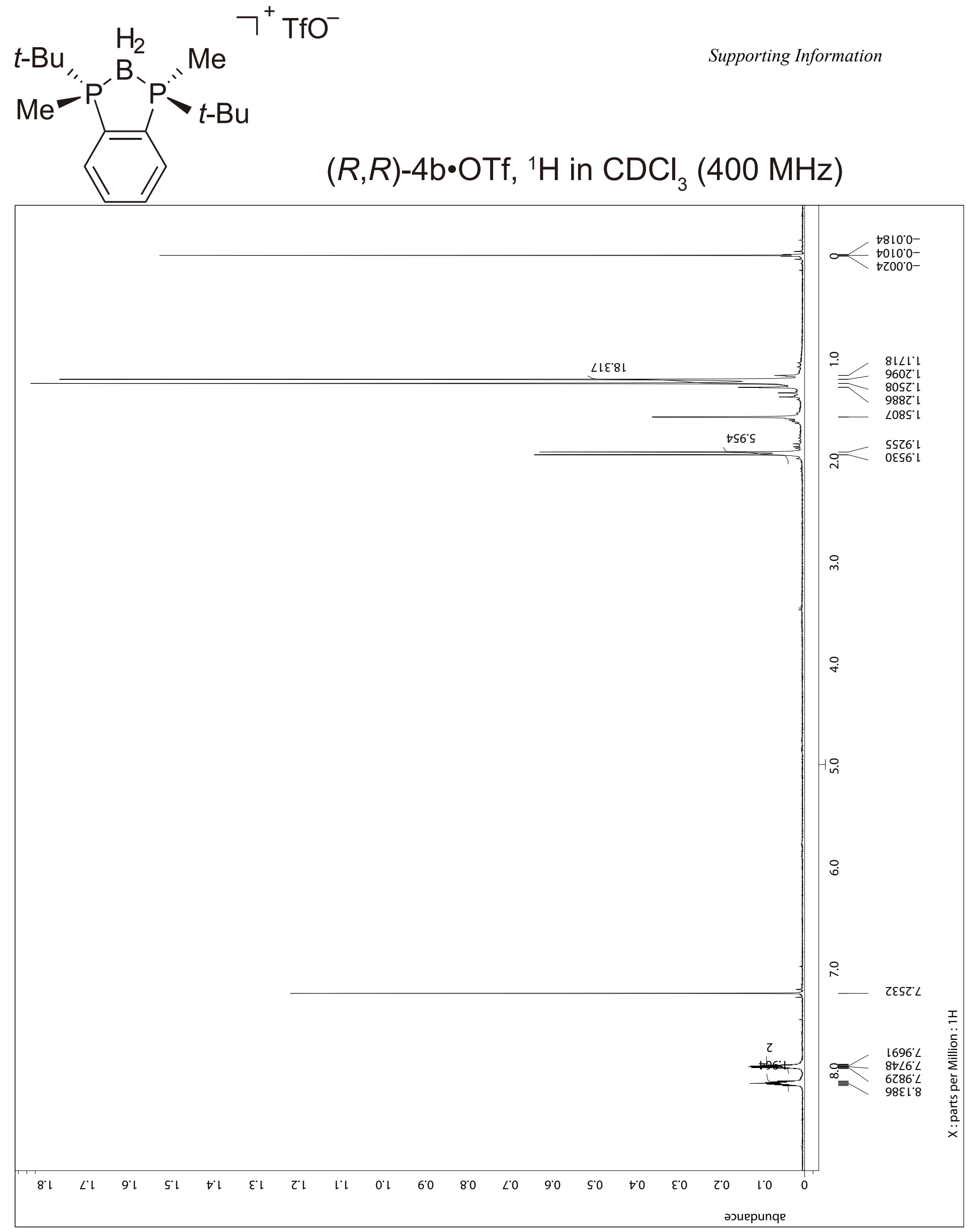




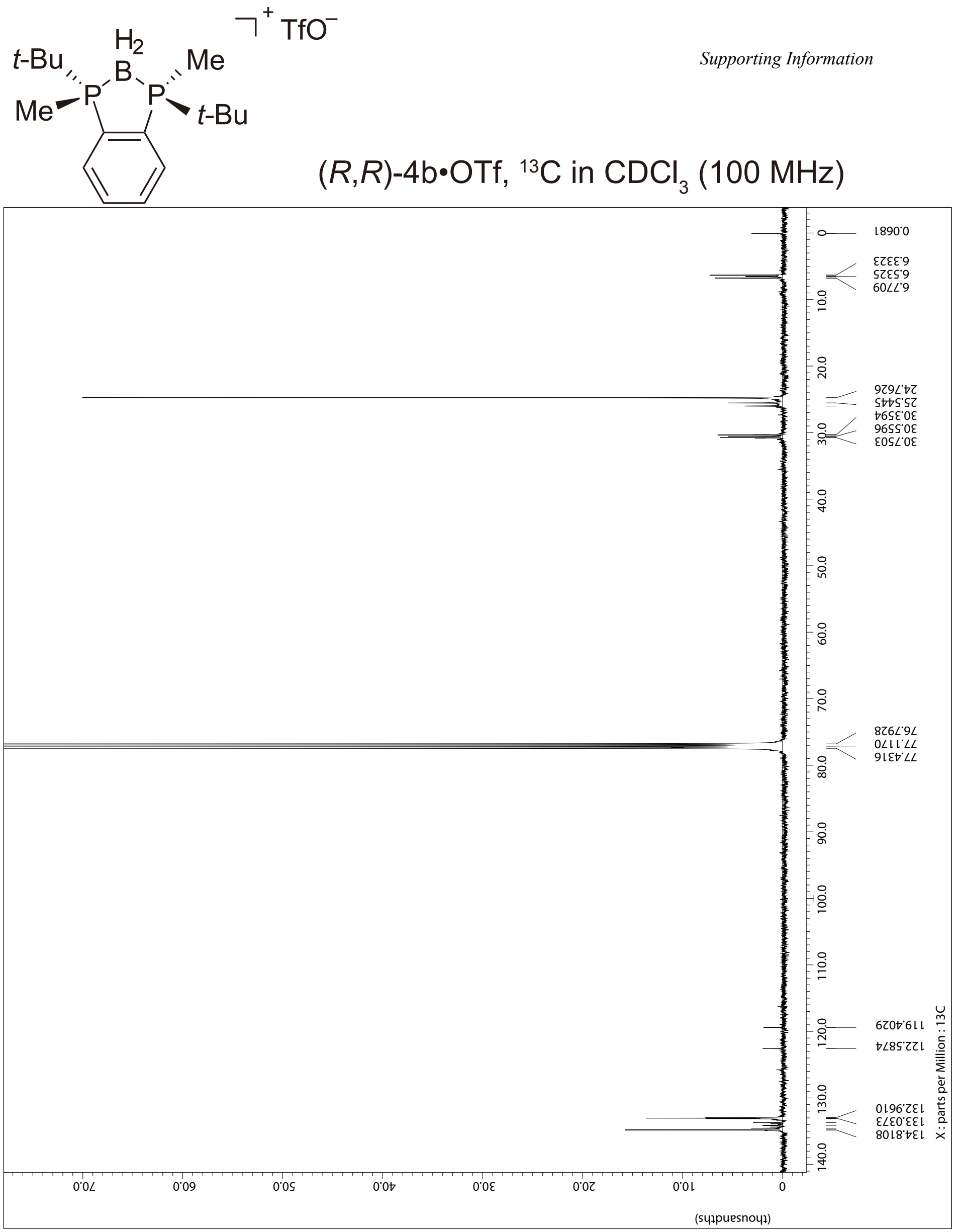




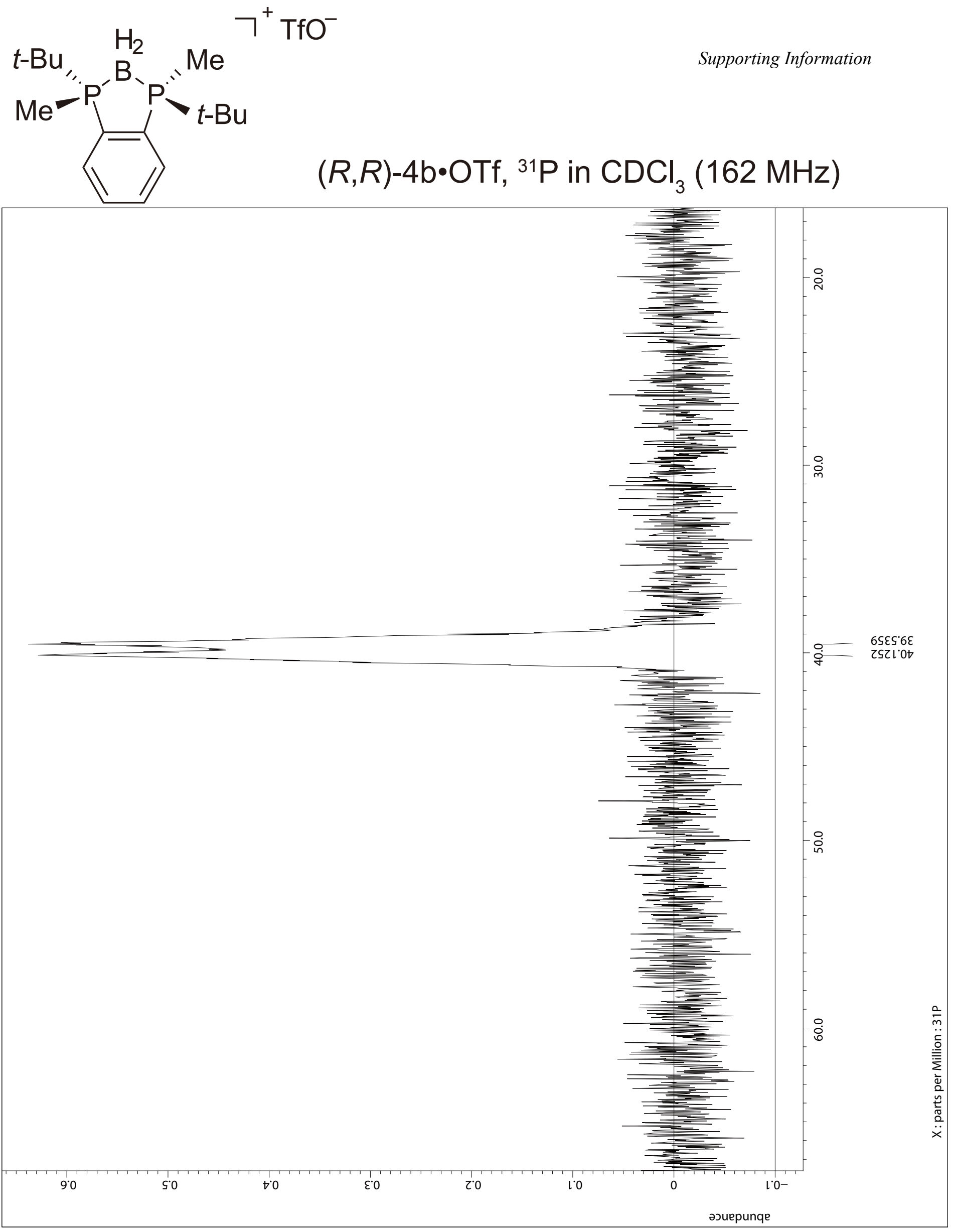

